NBER WORKING PAPER SERIES

THE ASSESSMENT OF NATIONAL PRICE LEVELS

Irving B. Kravis

Robert E. Lipsey

Working Paper No. 1912

NATIONAL BUREAU OF ECONOMIC RESEARCH

1050 Massachusetts Avenue

Cambridge, MA 02138

May 1986

The research reported here is part of the NBER's research program in International studies. Any opinions expressed are those of the authors and not those of the National Bureau of Economic Research. 


\title{
The Assessment of National Price Levels
}

\begin{abstract}
This paper attempts to find norms for long-run national price levels, and therefore, by implication, for exchange rates, that are superior to those implied by the absolute or relative versions of purchasing power parity theory. The structural variables we have found to determine these price levels, real income per capita, the openness of the cconony, and the share of tradables in total output, are used to explain price levels in periods since 1960 and to some extent since 1950.

The results suggest that there was a movement toward a nore "orderly" alignment of price levels, especially in the period before the 1970's. That is, national price levels came to be explained to an increasing degree by our structural variables.

The price levels implied by the structural equations appear to come closer to representing long-run equilibrium levels than do those implied by purchasing power parity. The deviations from the structural equations seem to have value in predicting, future changes in price levels or real exchange rates, in combination with changes in the structural variables. And they also contribute to predicting, changes in the balance of trade.
\end{abstract}

Irving B. Kravis

Department of Economics University of Pennsylvania 3718 Locust Walk Philadelphia, PA 19104
Robert E. Lipsey

NBER

269 Mercer Street

8th Floor

New York, NY 10003 
The Assessment of National Price Levels

Int roduction

I. Background

The price level and the real exchange rate 4

$\begin{array}{ll}\text { Previous work } & 7\end{array}$

II. The price level for GDP 11

The structural equation for PL 11

Trends in the key variables 14

Trends in the structural relationships 15

Alternative norms for price levels 19

Price levels for tradables and nontradables 23

III. Deviations from the structural equations

and their significance 25

The pattern of residuals 25

Residuals for tradables and nontradables 29

Price level deviations and the current

account balance 30

IV. Summary and agenda for future research 32

V. List of references 35

$\begin{array}{ll}\text { VI. Appendix } & 37\end{array}$ 
The Assessment of National Price Levels

Irving B. Kravis and Robert E. Lipsey

RESEARCH SUMMARY

\section{Synopsis}

Issues: Is there a standard for judging national price levels, and therefore exchange rates, that is superior to the criterion that they should be equal in all countries? Equality is the norm set by the purchasing power parity theory. In this paper we ask whether there are long-run determinants of national price levels that keep some of them (the U.S., for example) above the world average and some of them below the average without necessarily producing adverse effects on the countries concerned or inducing any movement of exchange rates toward equality of price levels.

Results: A country's national price level for all the goods and services that make up GDP is determined to a large extent by its real per capita income, the degree of openness of its economy, and the proportion of its aggregate output that consists of nontradables, mainly services. The higher the income level and the higher the proportion of nontradables, the higher the price level in the long run. A more open economy tends to have a higher price level if it is a poor country but a lower price level if it is a rich country.

The degree to which these characteristics explain national 
price levels increased over the last thirty years or so. That is, the structure of international price levels became more orderly. During the 1950's, the dispersion in price levels (deviations from purchasing power parity) decreased. In later years, the dispersion increased, but more and more of it was explained by these structural variables. Not only do the structural variables explain differences in price levels at a given time but changes in these variables help to explain changes in price levels. Thus a rise in a country's relative income level tends to raise the country's relative price level.

Deviations from the price levels implied by our equations tend to be persistent over the medium term but disappear over long periods. In contrast, deviations from equality of price levels appear to be permanent; a country with a high price level in one period is likely to have a high price level twenty years later.

\section{Policy Implications}

Measures taken to influence exchange rates are really aimed at affecting national price levels. Such efforts require a notion of what is in some sense an appropriate price level for a country and of what is an inappropriate level. We find strong evidence that the U.S. price level can be expected to be, typically, above that of almost any other country, mainly because the U.S. has the highest, or one of the highest, per capita income levels. For the same reason, we should expect that countries such as Italy, the United Kingdom, and Japan will tend to have lower price levels than the U.S. and most major European countries. The developing 
countries will typically have still lower price levels.

One implication of these results is that, since these relationships seem to be very durable, they are not indications of disequilibria in exchange rates. Efforts to move these price levels toward equality might well be futile or disruptive.

Further Research

Although we have succeeded in explaining much of the variance in price levels with the structural variables we have included, considerable unexplained deviations remain and appear to be fairly persistent. It would be desirable to search further for possibly omitted structural variables. Beyond that, the next step should be a search for short-run influences that produce short-run deviations from the structural relationships. These influences would include monetary and fiscal developments and capital flows, although the last may be quite long-lasting in their effects.

We have made a first effort to judge the effects of high or low price levels, relative to the expected ones, on a country's trade, but that is a subject that needs further investigation. For example, does a persistently high price level lead to a long-run trade deficit, or does it lead a country to participate less in world markets without unbalancing trade? Does a brief episode of high prices relative to long-run national price levels produce temporary trade deficits? 

THE ASSESSMENT OF NATIONAL PRICE LEVELS ${ }^{1}$

Int roduction

It has been evident for some time that there are large country to country differences in national price levels. Equality of price levels-sometimes referred to as the "law of one price" or "purchasing power parity"2--is not the norm. International comparisons of prices and incomes from the UN International Comparison Project (ICP) have shown that price level disparities of ten involve spreads of 2 to 1 and can be as big as 3 to 1 (Kravis, 1984; Kravis, Heston and Summers, 1982). Other independent investigations lead to the same conclusion. ${ }^{3}$ Also, the time-to-time variability of exchange rates in recent years, clearly unmatched by the changes in price

$1_{\text {We }}$ are indebted for valuable suggestions to the participants in two meetings of the AEI-NBER project on Real-Financial Linkages in Open Economics, particularly Robert Feenstra, Peter Hooper, Paul Krugman, and David Richardson, and also to participants in a session at the annual meeting of the Western Economic Association in 1985 and a seminar at the Graduate Center of the City University of New York. We are grateful to Linda Molinari and David Robinson for programming and statistical work and to Nancy Bansall, James Hayes, and Rosa Schupbach for preparation of the manuscript.

This research was done mainly as part of the National Bureau of Economic Research studies of U.S. Trade Policy, Competitivensss, and Capital Mobility in the World Economy (NSF Grant No. PRA-8116459) and is part of the NBER program in International Studies. Any opinions expressed are those of the authors and do not represent those of the NBER or the sponsoring agency.

2 "Purchasing power parity" in this sentence is used in the sense of Cassel's theory holding that price levels will be equal after conversion to a common currency via exchange rates. Elsewhere (for example, Kravis, Heston, and Summers, 1982; Kravis and Lipsey, 1983; and Kravis, 1984), the term has been used in an empirical sense to denote the number of currency units having the same purchasing power as a unit of a numeraire currency, usually the U.S. dollar. The term is employed in both senses in this paper; the context should make it clear which meaning is intended.

${ }^{3}$ For example, a recent report by Peter Hill (1985) of work by the OECD showed the 1984 price levels of 18 member countries varying from 52 per cent of the U.S. (Spain) to 97 per cent (Finland). Another study, this one carried out by the Statistical office of the European Community covering 15 African countries found 1980 price levels varying from 56 per cent of the average for the 15 (Ethiopia) to 126 per cent (Nigeria). 
levels called for by the theory, have tilted the weight of opinion against the validity of the relative version of the purchasing power parity theory. offsetting changes in international price movements and in exchange rates are not the norm either.

Nevertheless, the purchasing power parity theory of exchange rates continues to be invoked as a reference point in discussions of exchange rate behavior, such as those relating to over- or under- valuation of currencies and overshooting. The implicit assumption of ten is made that the exchange rates of some past period were normal and that equilibrium will be attained when the exchange rates of that period, or the exchange rates adjusted for differences in inflation (real exchange rates) are restored. In the latter case, the assumption is that the "real exchange rate" would be constant in equilibrium. This means, in other words, that the relationship between the price levels of different countries would be constant. A large part of the reason for the use of the PPP theory in these contexts is that there is no other reference point.

This paper represents an attempt to provide an alternative (see also work along these lines by Clague, 1986). Our approach is based on the notion that there is a structural relationship between price levels and basic national economic characteristics, such as per capita income and propensity to trade. We investigate the hypothesis that the price level of each country tends toward a norm, changing slowly over time, which can be established on the basis of this structural relationship, rather than on the assumption of identical price levels or identical changes in price levels. Price level differences in this view may be expected to be persistent, and they are not 
necessarily inconsistent with trade equilibrium. While the relationships of the price levels of different countries are determined by long-run factors, short-run influences can cause price levels to deviate from their structural norms.

Some of these issues were explored in terms of a 1975 cross section in an earlier paper (Kravis and Lipsey, 1983). In the present paper we extend the investigation to the period 1960-83, focusing on explaining long- or intermediate-term movements of price levels.

The international differences in price levels provide a link between the price level, which can be regarded as a financial variable, and the key real variables in the economic system. In some versions of the monetary theory of the balance of payments, the law of one price is assumed to prevail and the price level is a financial variable with little or no lasting effects. In the view taken here, which we believe reflects reality better, the general price level for GDP as a whole has imbedded in it sets of prices that can and do differ from country to country, thereby directly and indirectly influencing the nation's transactions with its trading and financial partners. Some of these prices affect the flows of goods; others the flows of capital. The literature dealing with the influence of prices on trade flows is voluminous; 4 that dealing with the role of prices in affecting capital flows is much sparser. Neither is assessed here; our focus is on the price level itself as an important link in the real-financial economic nexus. However, we do investigate whether deviations from our price level "norms" have any power in

\footnotetext{
${ }^{4}$ For a current example with some further references, see Bushe, Kravis, and Lipsey (1986).
} 
predicting changes in trade balances.

\section{Background}

The Price Level and the Real Exchange Rate

The price level (PL), upon which this work focuses, is defined as the ratio of the purchasing power parity of a currency (PPP) to its exchange rate (ER), both taken relative to the U.S. dollar as the numeraire currency. 5 Purchasing power parity is defined in turn as the number of units of a currency that have the same command over GDP as a U.S. dollar. Reliable purchasing power parities require careful price comparisons for a sample of commodities and services representative of GDP. 6 then the extrapolations on which this paper is based were performed, parities for 1975 were available from the U.N. International Comparison Project (ICP) for 34 countries. ${ }^{7}$ The basic data used in this paper are these purchasing power parities extrapolated on an annual basis backward, for the most part to 1960, and forward to 1983, using each country's implicit GDP deflators. For some of the 34 countries, data necessary for the analysis were not available for all the years of the period, and the discussion in this paper is therefore based on 25 or sometimes only 19 countries. ${ }^{8}$ In some cases countries were dropped because

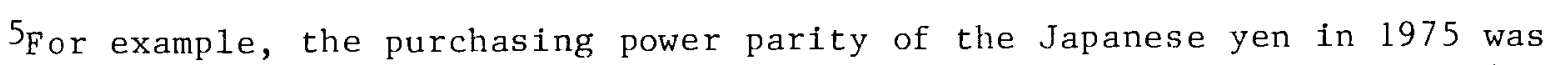
271 per U.S. dollar and the exchange rate 297/\$. Thus, with the U.S. dollar as the numeraire, set equal to 100 , the Japanese price level in 1975 was 91 .

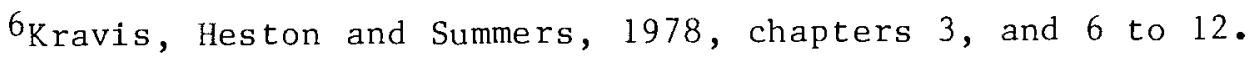

${ }^{7}$ Kravis, Heston and Summers 1982. Since that time, a limited set of data for 1980 has become available from the fourth round of the ICP.

${ }^{8}$ The 25 countries are listed in Table 1 . The exclusions that reduce the list to 19 are noted in Table 8 . 
exchange rates that reflected the large preponderance of the country's international transactions were not available. In other instances data on the division of GDP between tradables and nontradables were missing for some years and it was not possible to construct figures on implicit deflators for tradables and nontradables. 9 Even for included countries, there are sometimes uncertainties about the choice of a representative exchange rate, especially in the cases of some developing countries. Errors in the exchange rates are imparted to the PLs and if the time-to-time movement of the exchange rate series is also different from the true series, errors are introduced also into our time-to-time movements of PL. Our focus on the price level differs from the usual formulation in terms of intertemporal indexes of "real exchange rates" found in the substantial theoretical and empirical literature on exchange rate determination. The

9 We work with two different sets of definitions of tradables and nontradables, one based on a subdivision of expenditures on GDP into various categories of final demand (e.g., shoes), and the other based on a subdivision of GDP according to its industrial origins (e.g., the leather industry, the shoe industry, etc.). The final demand categories--representing purchases not intended for resale--are used in the UN International Comparison Project and are followed here when equations based directly on ICP data are presented. The final demand classification is not available for other years on a comparable basis. Use has therefore been made of a definition of tradables based on more widely available industry-originating data: the output of agricultural, mining, and manufacturing industries has been regarded as tradable and the rest of GDP as nontradable. The industry-originating classification, of course, includes both final and intermediate goods directly; the final demand classification includes intermediate goods only as part of the value of final goods. While the dividing line between tradables and nontractables in the industry-originating classification is somewhat arbitrary, it does distinguish groups of industries that in the aggregate differ a great deal with respect to the importance of trade. For the group of industries we include under tradables, the ratios of exports to output and imports to output in the U.S. in 1976 were each around 9 to 10 per cent. For the group we include under nontradables, aside from general government, the ratios were under 2 per cent (U.S. Departinent of Commerce, 1983, Table 1). 
most common definition of the real exchange rate (RER) refers to the intertemporal movement of the nominal rate corrected for the relative movement of prices in the given country and the numeraire country (see, for example, Krueger, 1983). ${ }^{10}$ The intertemporal index of PL (IPL), on the other hand, can be regarded as the movement of a country's own-currency price level corrected for the movement of the nominal exchange rate. Thus the RER and IPL are reciprocals, provided that the same price indexes are used in constructing the two measures. We have argued elsewhere that the implicit GDP deflator is the appropriate one to use, although the wholesale price index and the consumer price index are of ten employed (Kravis and Lipsey, 1978, p. 199-201). We prefer the "IPL" concept to "RER" because IPL is a more natural companion to PL in analyses involving the comparison of levels as well as intertemporal changes. Formulating the problem in terms of both comparative price levels and changes in price levels permits us to examine the possibility that it is the levels that identify disequilibrium situations; a country is in disequilibrium because its prices are too high rather than because they have risen. A change in price levels through changes in either exchange rates or relative own-currency inflation rates may be a response to an unsustainable price level.

\footnotetext{
$10^{\text {The }}$ real exchange rate is sometimes defined in theoretical literature as the change in the price of tradables relative to that of nontradables (e.g., Berglas and Razin). This definition is appropriate only if the price of tradables is the same at home and abroad (or if not the same, in a constant relationship). Among 25 ICP countries (15 developing and 10 developed) the price level for tradables varied in 1975 from 46 percent (Pakistan) to 144 percent (Denmark) of the U.S. level. ICP data are from Kravis, Heston and Summers, 1982. The classification used in that work groups construction with commodities rather than with services. However, for the tradables-nontradables dichotomy, as already noted, commodities excluding, construction are regarded as tradables and services plus construction as nontradable.
} 
In today's world of floating rates, the actual levels of prices and their rapid shifts can be arting. This may be illustrated by the following data showing very large changes in relatively short periods of time for major countries.

$$
\frac{\text { Price levels for GUP }}{\text { US }=100}
$$

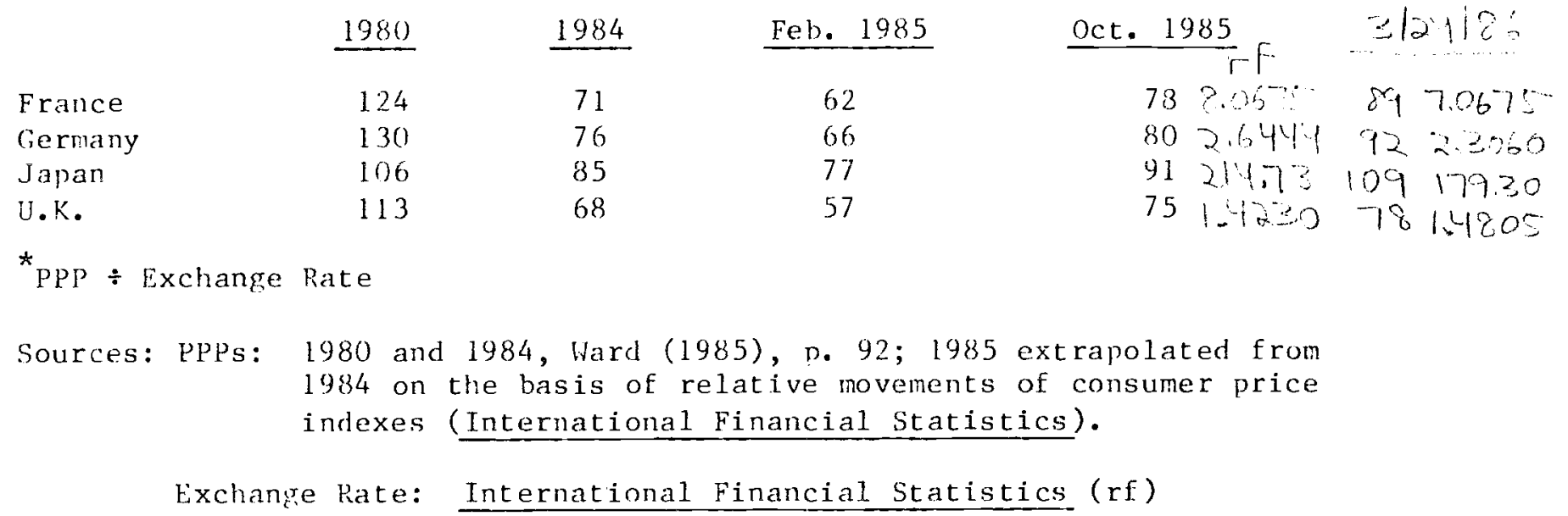

$\underline{\text { Previous Work }}$

The starting point for the present effort was a pair of equations that were found in Kravis and Lipsey (1983) to account for over 80 per cent of the cross-country variation in the national price levels of 34 countries in 1975. The price level (PL) was taken as the dependent variable, and the independent variables were real GOP per capita $(r)$, openness $(O P$ ) defined as exports plus imports (from national accounts data) divided by GDP, and the share of nontradables in final expenditures on GDP (SN). Corresponding, equations based on the 25 ICP countries used for this papertl are as follows:

\footnotetext{
11 The variables are scaled differently in the present equations; the U.S. is set equal to 100 for PL and $r$; OP is entered as a ratio and SN as a percentage. The mean $\mathrm{PL}$ for the 25 countries is 70.2 . Some minor corrections in the price levels have also been mate. t-values are in parentheses below the coefficients.
} 


$$
\operatorname{PL}(75)=\begin{gathered}
24.20 \\
(4.48)
\end{gathered}\left(\begin{array}{c}
.897 \mathrm{r} \\
(11.19)
\end{array}\right.
$$

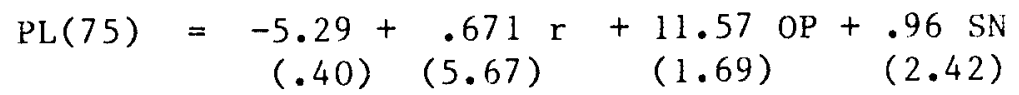

$$
\begin{aligned}
R^{2} & =.852 \\
\text { RMSE } & =12.3 \\
\text { No.Obs. } & =25
\end{aligned}
$$

$$
\begin{aligned}
\overline{\mathrm{R}}^{2} & =.879 \\
\mathrm{RMSE} & =11.1 \\
\text { No.O bs. } & =25
\end{aligned}
$$

Equations such as these for single years are subject to a good deal of short-run variability. Since this paper is focused on relatively long-term or medium-term changes, we rely on equations based on averages for three-year periods. We show the one-year equations here only for comparison with the earlier work.

The latest round of the ICP, for 1980, covers a much larger number of countries, but at this point data are available only for the variables of equation 1. For 55 countries in 1980, the corresponding equation is:
PL $(80)$
$42.56+.662 \mathrm{r}+17.54 \mathrm{OP}$
$(7.27) \quad(8.50) \quad(2.00)$
$\bar{R}^{2}=.623$
RMSE $=17.4$
No.Obs. $=55$

The explanatory power is much lower in the later equation than in equation (1) and the coefficient for $r$ is also much lower. There are two possible explanations for the difference. One is that the relationship did change over time; the other is that the additional countries, mainly developing, added in the broader survey did not exhibit the same relationship between price level and the other variables as the smaller group. We can test for the source of the difference by running the equation with 1980 data for those countries (25) for which 1975 data were also available. The list of countries is not identical to that included in the rest of this paper, but 22 of the 25 are the same. (Ireland, the Netherlands, and Spain are included here but Jamaica, Malaysia, and Pakistan are excluded). That equation is: 


$$
\operatorname{PL}(80)=\underset{(4.43)}{32.11}+\underset{(8.55)}{.856} \mathrm{r}+\underset{(1.93)}{(1.36} \mathrm{OP}
$$

$$
\begin{aligned}
\overline{\mathrm{R}}^{2} & =.785 \\
\text { RMSE } & =16.0 \\
\text { No.Obs. } & =25
\end{aligned}
$$

The resulting equation is very close to equation 1 with respect to the size of the constant term, the coefficient of $r$, and the $\bar{R}^{2}$ despite the difference in country coverage. Thus, it seems safe to say that there was no major change in the relationship from the substitution of 1980 relative prices and quantities for those of 1975. However, the addition of more countries did blur the relationship considerably, particularly because three newly-added low-income African countries, Cameroon, Nigeria, and the Ivory Coast, had extremely high price levels, two even above that for the U.S.

The rationale for the selection of the explanatory variables has been previously explained (e.g., Kravis and Lipsey, 1983, pp. 11-16, and Bhagwati, 1984), but it may be worthwhile to outline the arguments briefly. We take the occasion also to develop a little further our use of the openness variable. The positive association between PL and $r$ is attributable to higher prices of nontradables relative to tradables in higher income countries. The explanation may be couched in terms of rich-country margins of superiority in productivity that are smaller for nontradables, expecially services, than for tradables, or in terms of the tendency for nontradables to be labor intensive and for labor to be more costly relative to other factors of production in high income countries than in low-income countries.

In general, we may expect high foreign trade/GDP ratios to reduce country-to-country divergences in price levels. Trade not only operates directly in pulling prices of tradables towards greater uniformity, but affects the prices of nontradables by tending to raise the prices of relati- 
vely abundant factors and lowering the prices of relatively scarce ones. If poor countries tend to have abundant labor, and if nontradables (comprised largely of services) tend to be labor intensive, the effects of openness can be predicted. As between two countries with equal low incomes, the one with the higher level of openness should have higher prices for nontradables and for GIP as a whole. As between two countries with equal high incomes, the one with the higher level of openness should have lower prices.

The justification we give for the openness variable implies that the direction of its influence should vary with the factor abundance of the country involved. If we assume that the level of real income per capita is a good proxy for capital abundance (or labor scarcity), we could include a term for the combination of real incone per capita ( $r$ ) and openness (OP), and the coefficient for this cross-product term should be negative. Equations $I C$ and $2 \mathrm{C}$ correspond to equations 1 and 2 with the addition of this term:

$$
\begin{aligned}
\mathrm{PL}(75)= & 15.56+1.047 \mathrm{r}+33.07 \mathrm{OP}-.27 \mathrm{rOP} \\
& (1.72)(7.01)(2.12)(1.18)
\end{aligned}
$$

$$
\begin{aligned}
\overline{\mathrm{R}}^{2} & =.855 \\
\text { RMSE } & =12.2 \\
\text { No.Obs. } & =25
\end{aligned}
$$

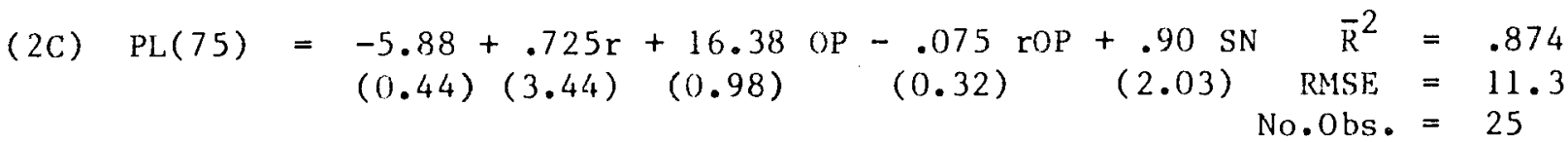

The rOP term meets our expectations in one respect but not in another. The coefficient is negative, as we expect, but it is not statistically significant and in this year at least, while the positive influence of openness on the price level diminishes with higher income, it never disappears or turns negative as we expected it would. 12

12 If we make the same addition of a term to the 1980 data used for equations $1 A$ and $I B$, we have:

(1AC) $\mathrm{PL}(80)=39.88+.711 \mathrm{r}+22.16 \mathrm{OP}-.08 \mathrm{rOP}$ $(3.73)(3.89) \quad(1.25) \quad(.30)$

$\begin{aligned} \vec{R}^{2} & =.616 \\ \text { RMSE } & =17.6 \\ \text { No.Obs. } & =55\end{aligned}$


Over time, the impact of OP may vary according to the direction of changes not only in op but also in the degree of responsiveness of internal prices to world markets. Increased and more rapidly diffused information nay result in a larger impact for a given level of openness than was observed in an earlier period.

The positive sign on the share coefficient, share being defined in terms of the current value of output in own prices, implies that, given real GUP per capita and openness, high nontradables shares in final expenditures are associated with high nontradables prices. Such a relationship may be attributable to elasticities of substitution between tradables and nontradables in final demand that are below 1.13

\section{The Price Level for GDP}

The Structural Equation for PL

The further explanation of comparative national price levels starts with the modification of equation (2) prior to fitting it to data for years other than 1975 in the period 1960-83. The formulation in equation (2) has the disadvantage that two of the independent variables, OP and $S N$, overlap. That is, OP may be regarded as the product of the share of tradables in GDP

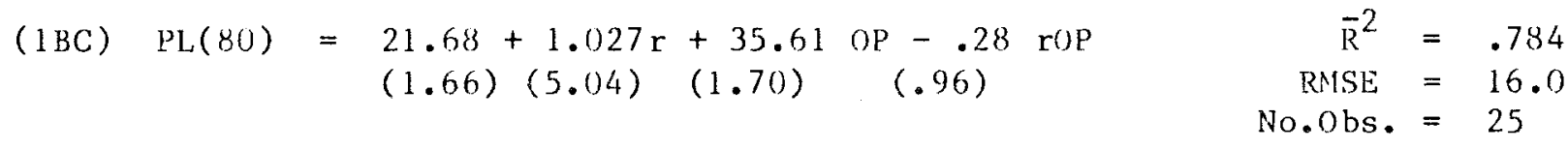

13 Since tradables prices are more nearly set by world prices, PL for GDP as a whole will be high when nontradables are dear, if the elasticity of substitution between tradables and nontradables in internal consumption is below 1 . The Phase III ICP data yield an elasticity of substitution between tradables and nontradables of -.44 (calculated from data in Kravis, Heston and Surmers, 1982, pages 12, col. 5; 194, cols. 8 and 9; and 196, cols. 8 and 9 for 30 countries). 
and the ratio of actually traded goods to tradables:

(3) $\mathrm{OP}=\frac{X+M}{\mathrm{GDP}}=\frac{X+M}{\text { Tradables }} \times \frac{\text { Tradables }}{\text { GDP }}$

An altermative way to decompose the independent variable is to substitute the two multiplicative components of $O P$ for $O P$ and $S N$. The results are:

$$
\operatorname{PL}(75)=\begin{array}{ccc}
87.84+.666 \mathrm{r} \\
(3.06)+5.71 \mathrm{OPT}
\end{array}-\begin{gathered}
.90 \mathrm{ST} \\
(5.65)
\end{gathered}
$$

$$
\overline{\mathrm{R}}^{2}=.879
$$

RMSE $=11.1$

No.Obs. $=25$

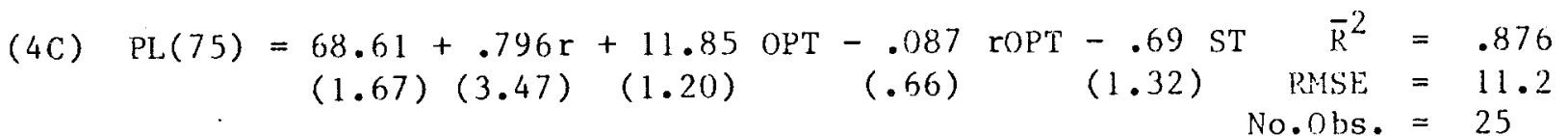

where $O P T=\frac{X+M}{\text { Tradables }}$ and $S T=$ the share of tradables in GDP. Equation (4C) again shows an attenuation of the influence of openness with higher levels of per capita income, but no reversal of direction.

There is no statistical basis for choosing between equations (2) or (2C) on the one hand and (4) and (4C) on the other, but (4) and (4C) nay be regarded as providing, a slightly better classification of the factors at work on the right side of the equation. The same rationale can be offered for OPT that was given for OP, and what was said about SN applies to ST with a changed sign. 14 It should be reported that the formulations of equations (2) and (4) were reached after an investigation of a larger number of structural variables (e.g., relative productivity in traded and nontraded goods), of different functional forms ( $\log$ versus arithmetic), and of different formulations of the

${ }^{14}$ When ST is substituted for SN, its coefficient is the same but with the opposite sign. The intercept term is altered. 
variables finally chosen (e.g., defining OP in terms of merchandise trade only). Although the choices were not always clear cut, some less than thorough investigation of the alternatives led us to believe that the results described below would not be very different if the alternative choices had been nade.

A problem encountered in the use of the (2) and (4) equations as prototypes for the investigation of long-run trends is that the ICP estimate of the share of tradables, used to form OPT and ST, is defined in terms of final products (i.e., goods purchased for final use and not for use as intermediate products) and is not readily available for other years. 15 This difficulty is not insuperable because a rough estimate of the tradables component of GDP can be derived from data, available in national accounts, on the share of GDP accounted for by different industries, each of which produces both final and intermediate products. For this purpose, as noted earlier, tradables have been defined as the output of agriculture, mining, and manufacturing, leaving the output of construction and of the service industries to be regarded as nontradables. The modified OPT and ST variables, OPTI and STI, respectively, produce similar results when substituted in equation (4):

\begin{tabular}{|c|c|c|c|c|c|c|c|c|c|}
\hline$(4 A)$ & PL(75) & $\begin{aligned}= & 56.42+ \\
& (2.75)\end{aligned}$ & $\begin{array}{l}.718 \mathrm{r} \\
(6.29)\end{array}$ & $\begin{aligned}+ & 6.03 \mathrm{OPT} 1 \\
& (2.50)\end{aligned}$ & $-i$ & $\begin{array}{l}.60 \text { STI } \\
(1.52)\end{array}$ & $\begin{array}{r}\bar{R}^{2} \\
\text { RMSE } \\
\text { No.O bs . }\end{array}$ & $\begin{array}{l}=.872 \\
=11.4 \\
=25\end{array}$ & \\
\hline$(4 \Lambda C)$ & $\operatorname{PL}(75)$ & $\begin{aligned}= & 36.06+ \\
& (1.64)\end{aligned}$ & $\begin{array}{l}.953 r+ \\
(5.87)\end{array}$ & $\begin{array}{l}17.00 \text { OPTI } \\
(2.78)\end{array}$ & $\begin{array}{l}-.16 \\
(1.93)\end{array}$ & rOPTI & $\begin{array}{l}-.45 \mathrm{STI} \\
(1.18)\end{array}$ & $\begin{array}{r}\overline{\mathrm{R}}^{2}= \\
\text { RMSE }= \\
\text { o.0bs. }=\end{array}$ & $\begin{array}{l}.886 \\
10.8 \\
25\end{array}$ \\
\hline
\end{tabular}

${ }^{15}$ see footnote 9. 
Even this version of the two trade exposure variables is available as far back as 1960 for only 25 countries and this was one of the facts that determined the restriction of the analysis to these countries. Trends in the Key Variables Since we are interested primarily in price level trends, we have recast the annual data into a series of non-overlapping three-year averages. These reduce the influence of short-term fluctuations and make the trends in the underlying data stand out more clearly.

The behavior of the four variables used in equation (4A) is presented in Table 1, with two versions of the openness variables reported. One of the major changes over the whole period is that the average price level relative to the U.S., after remaining in the range of 56 to 59 per cent of the U.S. level during the fixed-exchange-rate period, climbed to nearly 80 per cent in 1978-80 before falling back to 65 per cent in 1981-83. It rose particularly during the two periods when there were major increases in petroleum prices (column 1). The dispersion of country price levels around their average increased (column 2); that is, deviations from the law of one price became larger. There was a particularly large jump in dispersion between the fixed exchange rate period and the floating exchange rate period, but the trend toward larger deviations began during the fixed rate period. The two decades witnessed a great expansion in the world economy 16 but, of course, not all countries gained at the same rate: the U.S. lagged behind the average of, the others, for example (column 3). The dispersion of

\footnotetext{
${ }^{16}$ See Kravis and Lipsey (1984).
} 


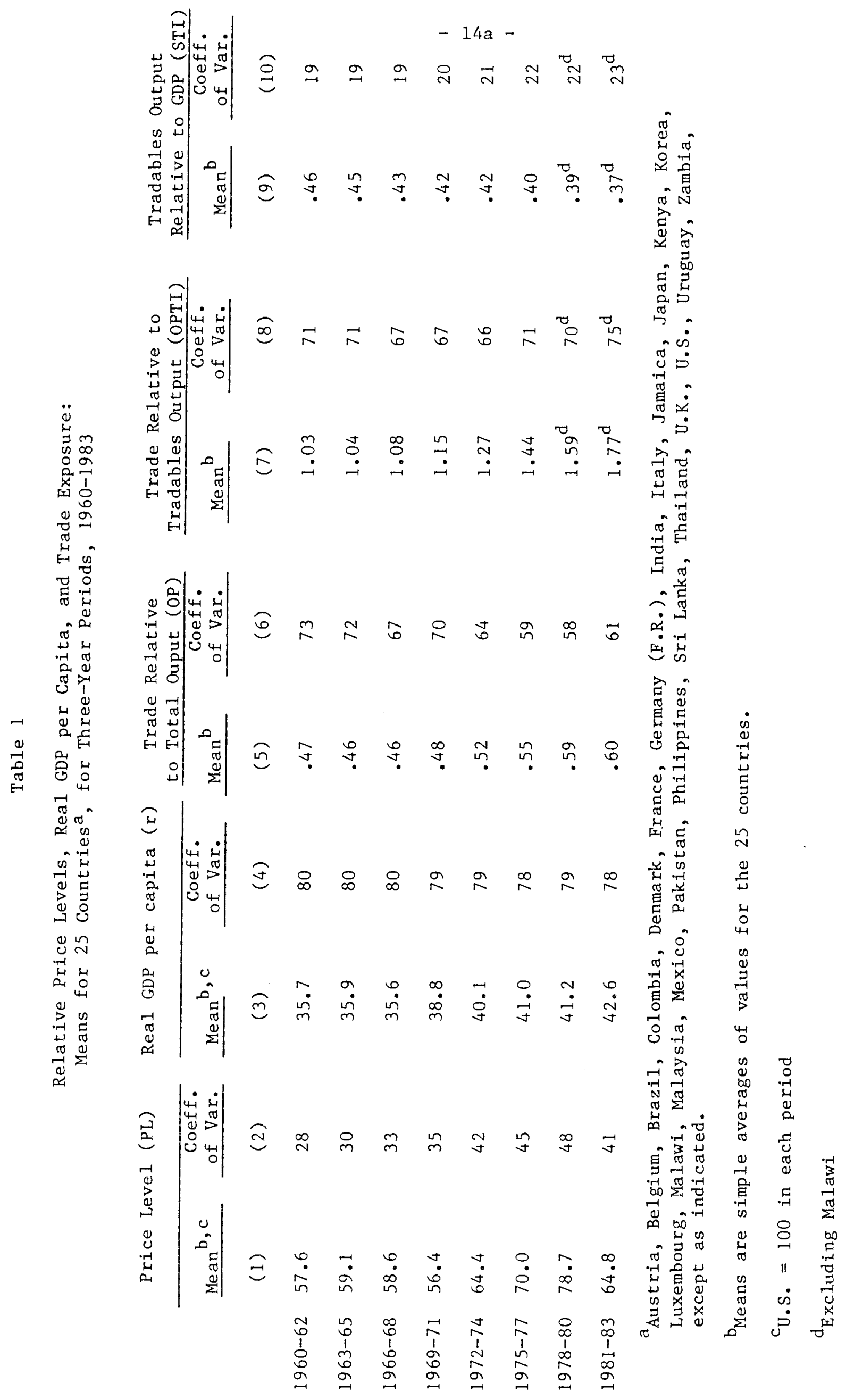


country incomes around the mean remained aimost constant (column 4).

The share of tradables in total GDP drifted downwards (column 9), as service industry output grew relative to goods output, but the ratio of goods actually traded to tradables output rose sharply, especially in the 1970 s (column 7). That rise in the trade ratio was partly a direct reflection of the increase in the price of oil, a heavily traded commodity, but was not confined to that group. It was evident also within manufactured goods (see Lipsey, $1984)$.

Trends in the Structural Relationships

Table 2 shows the results of fitting, equations like (4A) to each of the 8 cross sections. It is evident that there were marked secular trends in the coefficients of real per capita GDP and openness. In each case, the coefficient tends to rise through time, with the increases tending, to be larger in the early 1970 s at about the the time that the Bretton Woods regime ended. That is, the price levels of the countries became more sharply differentiated according to their income levels and the extent of their participation in the international econony. At the same time, the explanatory power of the independent variables increased markedly; the t-statistics and the $\bar{R}^{2}$ s are clearly higher in the later periods. The "unexplained" deviations from the law of one price therefore increased much less than the deviations themselves.

To trace the changes in these relationships back to the $1950 \mathrm{~s}$, it is necessary to revert to equation (1) and to rely on data for a smaller number of countries. In Table 3, the results of equation (1) are presented for 23 countries based on data for 1950-1962 and for the same 25 countries as in Table 2 for 1960-1983, with 1960-62 as an overlapping period. 
Table 2

Price Level (PL) as a Function of Real Per Capita GDP ( $r$ ), Trade as Proportion of Tradables Output (OPTI) and Share of Tradables Output in GDP (STI)

$$
\text { 3-Year Periods, 1960-83 }
$$

\begin{tabular}{|c|c|c|c|c|c|}
\hline & Intercept & $\mathrm{r}$ & OPTI & STI & $\overline{\mathrm{R}}^{2}$ \\
\hline & (1) & (2) & (3) & (4) & (5) \\
\hline $1960-62$ & $\begin{array}{l}60.70 \\
(3.92)\end{array}$ & $\begin{array}{l}.389 \\
(4.48)\end{array}$ & $\begin{array}{c}.25 \\
(0.09)\end{array}$ & $\begin{array}{r}-.38 \\
(1.31)\end{array}$ & $\begin{array}{l}.642 \\
(9.6)\end{array}$ \\
\hline $1963-65$ & $\begin{array}{l}57.49 \\
(3.40)\end{array}$ & $\begin{array}{l}.456 \\
(4.77)\end{array}$ & $\begin{array}{c}.56 \\
(0.20)\end{array}$ & $\begin{array}{l}-.34 \\
(1.09)\end{array}$ & $\begin{array}{l}.700 \\
(9.8)\end{array}$ \\
\hline $1966-68$ & $\begin{array}{l}48.91 \\
(2.90)\end{array}$ & $\begin{array}{l}.537 \\
(5.53)\end{array}$ & $\begin{array}{l}1.54 \\
(0.54)\end{array}$ & $\begin{array}{l}-.26 \\
(0.79)\end{array}$ & $\begin{array}{l}.747 \\
(9.7)\end{array}$ \\
\hline $1969-71$ & $\begin{array}{l}40.36 \\
(3.25)\end{array}$ & $\begin{array}{l}.567 \\
(7.90)\end{array}$ & $\begin{array}{l}.64 \\
(0.29)\end{array}$ & $\begin{array}{l}-.16 \\
(0.65)\end{array}$ & $\begin{array}{l}.836 \\
(8.0)\end{array}$ \\
\hline $1972-74$ & $\begin{array}{l}39.09 \\
(2.29)\end{array}$ & $\begin{array}{l}.714 \\
(7.32)\end{array}$ & $\begin{array}{l}3.96 \\
(1.46)\end{array}$ & $\begin{array}{l}-.20 \\
(0.60)\end{array}$ & $\begin{array}{l}.856 \\
(10.3)\end{array}$ \\
\hline $1975-77$ & $\begin{array}{l}57.48 \\
(2.50)\end{array}$ & $\begin{array}{l}.673 \\
(5.14)\end{array}$ & $\begin{array}{l}6.12 \\
(2.16)\end{array}$ & $\begin{array}{l}-.59 \\
(1.31)\end{array}$ & $\begin{array}{l}.842 \\
(12.6)\end{array}$ \\
\hline $1978-80$ & $\begin{array}{l}43.76 \\
(1.55)\end{array}$ & $\begin{array}{l}.913 \\
(5.88)\end{array}$ & $\begin{array}{l}6.79 \\
(2.16)\end{array}$ & $\begin{array}{l}-.34 \\
(0.60)\end{array}$ & $\begin{array}{l}846 \\
(15.0)\end{array}$ \\
\hline $1981-83$ & $\begin{array}{l}61.56 \\
(3.28)\end{array}$ & $\begin{array}{l}.605 \\
(6.03)\end{array}$ & $\begin{array}{l}.29 \\
(0.15)\end{array}$ & $\begin{array}{l}-.62 \\
(1.55)\end{array}$ & $\begin{array}{l}.831 \\
(10.7)\end{array}$ \\
\hline
\end{tabular}

The dependent variable is PL with the U.S. = 100 in each period. All variables are three-year averages. 25 observations in each period, except 1978-80 and 1981-83 when Malawi is missing. The omission of Malawi has virtually no effect on the coefficients for the period before 1978 .

$\mathrm{PL}=\mathrm{PPP} /$ Exchange rate.

Figures in parentheses are t-statistics in columns $1-4$ and root mean square errors in column 5 .

Independent variables:

$r=$ real per capita GDP with the U.S. = 100 in each period. OPTI $=(X+M) /$ Tradables, based on national accounts data. Tradables based on shares of agriculture, mining and manufacturing components of GDP.

STI = Tradables as $\%$ of GDP, with tradables based on national accounts data for agriculture, mining and manufacturing.

Note: $\overline{\mathrm{R}}^{2} \mathrm{~s}$, intercept terms, and standard errors are the same whether the absolute or relative values of the variables are used (i.e., whether per capita GDP is expressed in dollars or, as is done, as an index with U.S. $=100$ ). 
$-15 b-$

Table 3

PL as a Function of Real Per Capita GDP and Openness;

3-year Periods, 1950-83

\begin{tabular}{|c|c|c|c|c|}
\hline Period & Intercept & $\mathrm{r}$ & $\mathrm{OP}$ & $\overline{\mathrm{R}}^{2}$ \\
\hline & \multicolumn{4}{|c|}{23 countries } \\
\hline $1950-52$ & $\begin{array}{r}62.18 \\
(5.5)\end{array}$ & $\begin{array}{l}.245 \\
(1.1)\end{array}$ & $\begin{array}{r}-10.39 \\
(0.6)\end{array}$ & $\begin{array}{l}-.032 \\
(25.8)\end{array}$ \\
\hline $1953-55$ & $\begin{array}{r}56.37 \\
(6.3)\end{array}$ & $\begin{array}{l}.305 \\
(1.7)\end{array}$ & $\begin{array}{r}-5.99 \\
(0.4)\end{array}$ & $\begin{array}{c}.039 \\
(20.4)\end{array}$ \\
\hline $1956-58$ & $\begin{array}{l}50.32 \\
(6.9)\end{array}$ & $\begin{array}{l}.345 \\
(2.4)\end{array}$ & $\begin{array}{l}3.60 \\
(0.3)\end{array}$ & $\begin{array}{l}.148 \\
(16.9)\end{array}$ \\
\hline $1959-61$ & $\begin{array}{r}43.50 \\
(7.8)\end{array}$ & $\begin{array}{l}.393 \\
(3.7)\end{array}$ & $\begin{array}{r}-0.19 \\
(0.2)\end{array}$ & $\begin{array}{c}.366 \\
(12.7)\end{array}$ \\
\hline \multirow[t]{2}{*}{$1960-62$} & $\begin{array}{c}41.99 \\
(9.0)\end{array}$ & $\begin{array}{l}.427 \\
(4.9)\end{array}$ & $\begin{array}{l}0 \\
(0)\end{array}$ & $\begin{array}{l}.525 \\
(10.8)\end{array}$ \\
\hline & \multicolumn{4}{|c|}{25 countries } \\
\hline $1960-62$ & $\begin{array}{r}41.24 \\
(10.2)\end{array}$ & $\begin{array}{l}.458 \\
(6.5)\end{array}$ & $\begin{array}{r}0.06 \\
(0.0)\end{array}$ & $\begin{array}{r}.630 \\
(9.8)\end{array}$ \\
\hline $1963-65$ & $\begin{array}{l}39.64 \\
(9.7)\end{array}$ & $\begin{array}{l}.528 \\
(7.5)\end{array}$ & $\begin{array}{l}1.11 \\
(0.2)\end{array}$ & $\begin{array}{r}.697 \\
(9.9)\end{array}$ \\
\hline $1966-68$ & $\begin{array}{l}35.77 \\
(8.7)\end{array}$ & $\begin{array}{l}.594 \\
(8.5)\end{array}$ & $\begin{array}{r}3.62 \\
(0.6)\end{array}$ & $\begin{array}{r}.751 \\
(9.6)\end{array}$ \\
\hline $1969-71$ & $\begin{array}{r}32.74 \\
(10.0)\end{array}$ & $\begin{array}{c}.599 \\
(11.1)\end{array}$ & $\begin{array}{r}.85 \\
(0.2)\end{array}$ & $\begin{array}{l}.840 \\
(7.9)\end{array}$ \\
\hline $1972-74$ & $\begin{array}{l}29.43 \\
(6.7)\end{array}$ & $\begin{array}{c}.781 \\
(11.4)\end{array}$ & $\begin{array}{c}7.02 \\
(1.1)\end{array}$ & $\begin{array}{r}.854 \\
(10.3)\end{array}$ \\
\hline $1975-77$ & $\begin{array}{l}26.12 \\
(4.5)\end{array}$ & $\begin{array}{l}.856 \\
(10.0)\end{array}$ & $\begin{array}{l}15.87 \\
(1.9)\end{array}$ & $\begin{array}{r}.827 \\
(13.1)\end{array}$ \\
\hline $1978-80$ & $\begin{array}{l}25.35 \\
(3.8)\end{array}$ & $\begin{array}{l}1.044 \\
(10.9)\end{array}$ & $\begin{array}{l}17.43 \\
(1.9)\end{array}$ & $\begin{array}{r}.847 \\
(14.9)\end{array}$ \\
\hline $1981-83$ & $\begin{array}{l}33.38 \\
(7.2)\end{array}$ & $\begin{array}{c}.719 \\
(10.3)\end{array}$ & $\begin{array}{c}1.26 \\
(0.2)\end{array}$ & $\begin{array}{r}.828 \\
(10.9)\end{array}$ \\
\hline
\end{tabular}


Notes to Tab1e 3

A11 variables are three year averages.

The dependent variable is PL with the U.S. = 100 in each period.

$\mathrm{PL}=\mathrm{PPP} / \mathrm{Exchange}$ rate.

Figures in parentheses are t-statistics in columns $1-3$ and root mean square errors in column 4 .

Independent variables:

$$
\begin{aligned}
r & =\text { real per capita GDP with the U.S. }=100 \text { in each period. } \\
O P & =(X+M) / G D P, \text { based on national accounts data }
\end{aligned}
$$

Note: $\overline{\mathrm{R}}^{2} \mathrm{~s}$, intercept terms, and standard errors are the same whether the absolute or relative values of the variables are used (i.e., whether per capita GDP is expressed in dollars or, as is done, as an index with U.S. = 100). 
The major story of Table 3 is that the movenent towards a more "orderly" alignment of PLs was very substantial during the 1950 s. 17 The equations for the first three periods do not even meet a test of significance at the 5 per cent level, but the degree to which our equations explained price levels, as measured by the $\overline{\mathrm{R}}^{2} \mathrm{~s}$, increased monotonically from the early 1950 s to the 1960 s and, in fact, through the early 1970 s, after which it changed only slightly. For a good part of the period, up to the end of the era of "fixed" exchanged rates, the standard error of the equations declined almost continuously. For the first couple of periods at least, that decline must have represented a fall in the variance of price levels themselves, that is, a move towards aligning exchange rates with the purchasing, power of currencies, since our equations showed no significant coefficients. After that, however, and particularly during the era of floating exchange rates, price levels came to be explained more and more by per capita income and openness, until the last period, when the openness variable suddenly vanished.

If we add the cross-product tern ropTI to the equations of Table 2 to permit the direction of the openness effect to vary with income level, we get the set of coefficients displayed in Table 4. The degrees of explanation and the standard errors are quite similar to those of the earlier table, but the openness coefficients are very different and show the expected interrelation with incone levels. In the last equation, for example, the coefficients imply

17 We should note, however, an alternative to the suggestion that the structure of price levels became more rational in some sense over time. It is conceivable that the price level estimates for the 1950s are very poor because they are extrapolated so far from the 1975 base. They do, however, match fairly well $\left(\overline{\mathrm{r}}^{2}=.73\right.$ and the average absolute difference is only about $\left.5 \%\right)$ the independent estimates made for that period by Gilbert and Kravis (1954) and Gilbert and Associates (1958) for the same countries, as can be seen fron the comparison in Summers, Kravis, and Heston (1980), p. 30 . 
Table 4

PL as a Function of Real Per Capita GDP(r), Openness (OPTI), Share of Tradables (STI) and rOPTI

25 Countries

3-year Periods, 1960-83

\begin{tabular}{|c|c|c|c|c|c|c|}
\hline & Intercept & $\mathbf{r}$ & OPTI & rOPTI & STI & $\overline{\mathrm{R}}^{2}$ \\
\hline $1960-62$ & $\begin{array}{l}51.38 \\
(2.94)\end{array}$ & $\begin{array}{r}.506 \\
(3.76)\end{array}$ & $\begin{array}{l}5.23 \\
(1.00)\end{array}$ & $\begin{array}{c}-.100 \\
(1.12)\end{array}$ & $\begin{array}{l}-.29 \\
(0.97)\end{array}$ & $\begin{array}{l}.646 \\
(9.5)\end{array}$ \\
\hline $1963-65$ & $\begin{array}{l}46.80 \\
(2.44)\end{array}$ & $\left(\begin{array}{r}.582 \\
(4.02)\end{array}\right.$ & $\begin{array}{l}6.39 \\
(1.10)\end{array}$ & $\begin{array}{c}-.105 \\
(1.15)\end{array}$ & $\begin{array}{l}-.24 \\
(0.74)\end{array}$ & $\begin{array}{l}.704 \\
(9.7)\end{array}$ \\
\hline $1966-68$ & $\begin{array}{l}40.64 \\
(2.27)\end{array}$ & $\begin{array}{l}.664 \\
(4.74)\end{array}$ & $\begin{array}{c}8.10 \\
(1.36)\end{array}$ & $\begin{array}{r}-.121 \\
(1.25)\end{array}$ & $\begin{array}{l}-.21 \\
(0.66)\end{array}$ & $\begin{array}{l}.753 \\
(9.6)\end{array}$ \\
\hline $1969-71$ & $\begin{array}{l}31.24 \\
(2.30)\end{array}$ & $\begin{array}{r}.690 \\
(6.32)\end{array}$ & $\begin{array}{c}6.98 \\
(1.44)\end{array}$ & $\begin{array}{c}-.106 \\
(1.46)\end{array}$ & $\begin{array}{l}-.10 \\
(0.40)\end{array}$ & $\begin{array}{l}.845 \\
(7.8)\end{array}$ \\
\hline $1972-74$ & $\begin{array}{l}19.95 \\
(1.06)\end{array}$ & $\begin{array}{r}.933 \\
(6.38)\end{array}$ & $\begin{array}{l}14.89 \\
(2.39)\end{array}$ & $\begin{array}{c}-.167 \\
(1.92)\end{array}$ & $\begin{array}{l}-.04 \\
(0.12)\end{array}$ & $\begin{array}{l}.873 \\
(9.7)\end{array}$ \\
\hline $1975-77$ & $\begin{array}{l}37.22 \\
(1.57)\end{array}$ & $\begin{array}{r}.916 \\
(5.32)\end{array}$ & $\begin{array}{l}19.64 \\
(2.71)\end{array}$ & $\begin{array}{r}-.183 \\
(2.00)\end{array}$ & $\begin{array}{l}-.49 \\
(1.15)\end{array}$ & $\begin{array}{c}.862 \\
(11.8)\end{array}$ \\
\hline $1978-80$ & $\begin{array}{l}36.29 \\
(1.19)\end{array}$ & $\begin{array}{r}1.017 \\
(4.72)\end{array}$ & $\begin{array}{l}12.03 \\
(1.50)\end{array}$ & $\begin{array}{r}-.072 \\
(0.71)\end{array}$ & $\begin{array}{l}-.33 \\
(0.56)\end{array}$ & $\begin{array}{c}.842 \\
(15.2)\end{array}$ \\
\hline $1981-83$ & $\begin{array}{l}45.87 \\
(2.13)\end{array}$ & $\begin{array}{r}.758 \\
(5.14)\end{array}$ & $\begin{array}{c}6.67 \\
(1.34)\end{array}$ & $\begin{array}{r}-.084 \\
(1.39)\end{array}$ & $\begin{array}{l}-.46 \\
(1.13)\end{array}$ & $\begin{array}{c}.839 \\
(10.5)\end{array}$ \\
\hline
\end{tabular}

For notes, see Table 2 . 
that the effect of a greater degree of openness on the price level is positive for any country with real income per capita less than 81 per cent of the U.S. level but negative for any country above that incone. The latter group included Denmark, France, and Germany in that year. The 52 per cent dividing line in 1960-62 suggested negative coefficients for the U.S. and all the European countries except Italy. The coefficient for Japan was always positive. There was considerable variation in the borderline over time, but in four of the eight periods the dividing line was between 52 and 67 per cent of the U.S. income level. The equations suggest that openness had a positive effect on price levels for all countries in the $1970^{\prime}$ s, particularly $1975-80$. That result confirms the failure to find any negative openness effect in the earlier single-year equations for 1975 and 1980.18

Aside from the increasing explanatory power of the equations, it is clear in all the sets of equations that the slope of the relationship between per capita incone and price level was rising over most of the period. The coefficients for openness had a different history. In equations without a cruss-product term (Tables 2 and 3), they played no role at all for the period of fixed exchange rates, increased in importance afterwards, and virtually disappeared in the last period. When the cross-product term rOP'T was added

18 Since the deviations from the regressions are highly correlated with each other across periods, as is discussed later, and the same variables are used in each regression, we used Zellner's "seemingly unrelated regression" procedure to estimate the whole set of cross-section equations simultaneously. The results, given in Appendix Table 1 are coefficients for per capita income and openness quite similar to those of Table 4. The t-statistics for the $r$ and STI variables increased, and the coefficients were slightly higher as well, but both were lower for the OPTI variable. Many of the OPTI coefficients were actually negative, although not statistically significant, in the earlier periods. Since the per capita income variable is so dominant and the changes in it were not large, we did not substitute the re-estimated coefficients in our analysis. 
(Table 4), both its coefficient and that of the OP term itself were more stable than the op or OPTI terms in Tables 2 and 3.19

The most likely explanation for the shifts in the coefficients over time is that there are important variables onitted from the analysis. One candidate for this role is capital movements. Since a capital importer is running a current account deficit, we might think of a high price level as part of the mechanism producing such a deficit, or of a low price level as part of the process that produces a current-account surplus. This variable would be appropriate if we thought of shifts in the capital account as exogenous, reflecting, forces in capital markets to which the current account must acconodate. It would be less appropriate if we thought of the capital account as accomodating changes in the determinants of the current account or of the two being deternined simultaneously. 20

\footnotetext{
19 An alternative to the interpretation of these changes as representing shifts in the structural coefficients might be that the basic relationship is constant through time but curvilinear. In this case, the higher coefficients for $r$ and OPT in the equations for the more recent periods could be due to their being fitted to a steeper part of the function. That seens an unlikely explanation for the most important explanatory variable, real GDp per capita as a percent of the U.S., since it increased only from 36 percent in 1960-68 to 42 per cent in 1981-83 (See Table 1). Of the other independent variables, the OP and OPTI measures, particularly the latter, increased substantially, while the share of tradtable goods in Glp edged downards, but these variables account for only a small fraction of the estimated price level.

A preliminary test of the 1980 data for a larger sample of countries from ICP Phase IV did not suggest curvilinearity in the relationships between $P L$ and either $r$ or OP. Squared terns for these two variables did not have significant coefficients, and their introduction only reduced the significance of the other variables.
}

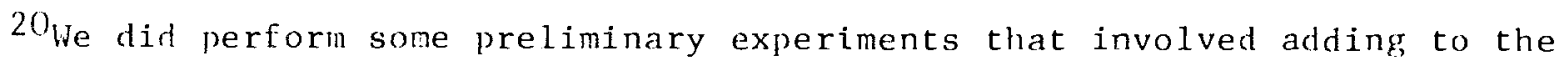
equations of Table 2 a variable for the ratio of the net current balance to GDP. The coefficients were never statistically significant and of ten had the wrong sign. The atdition of this variable did not affect the coefficients of the other variables. 
Over the last 15 or 20 years, the changing institutional background has continually brought new or newly important influences into the determination of exchange rates and price levels. The shift fron fixed to floating, rates and the enornous rise in the importance of capital movements, mentioned above, are only two of many. These changes are difficult to capture in econometric formulations. We have made no effort to measure the factors affecting, exchange rates separately fron domestic price levels or short-term effects on international price levels, and little effort to measure the effects of changes in the institutional climate. What is attempted here is to identify and take systematic account of certain permanent factors: those that tend to remain in play continuously. Some important factors that are relatively new and often difficult to quantify appear only as factors changing our coefficients or are left to be explained, possibly in nore qualitative terms, as part of large and economically significant residuals.

Alternative Norms for Price Levels

The differences between the price levels implicit in one set of equations and those implicit in the purchasing, power parity theory of exchange rates are described in Table 5. We compare the deviations from the price levels implied by the absolute form of the theory (all PL $=100)$ with the residuals from the equations of Table 2 (PL-PL). The results of the conparison are, of course, a foregone conclusion, given the high $\mathrm{k}^{2} \mathrm{~s}$ of Table 2 . Any significant relation between the price level and our independent variables implies that our equations fit better than the purchasing power parity assumption, the absolute form of which implies identity of price levels. This comparison is not a test of the predictive power of our struc- 
Table 5

\section{Measures of Closeness of Fit to Actual Country Price Levels $\left(\mathrm{PL}_{1}\right)$ : Structural Equations Compared with Absolute Version of Purchasing Power Parity Theory}

$\frac{\begin{array}{c}\text { PPP } \\ \text { Theory }\end{array}}{(1)} \quad \frac{\begin{array}{c}\text { Table } 2 \\ \text { Equation }\end{array}}{(2)}$

Mean absolute deviation
A11 periods
21.4
15.4
7.6
First 4 periods*
27.4
6.3
Last 4 periods**
8.8

Mean squared deviation

A11 periods

625

First 4 periods*

322

99

Last 4 periods**

927

73

126

\footnotetext{
*1960-62, 1963-65, 1966-68, and 1969-71.

** $1972-74,1975-77,1978-80$, and 1981-83.

${ }^{a} L_{i}-$ Average $P L$

$\mathrm{b}_{\mathrm{PL}_{\mathbf{i}}}-\hat{\mathrm{PL}}_{\mathbf{i}}$
} 
tural equations, since they have been fitted to the price levels of each period. Even so, it is of some interest that the fit can be so good using a common set of independent variables for all the periods, without taking into account the many short-term factors that can cause price levels to change if own-price inflation rates and changes in exchange rates are not exactly offsetting.

Several tests of predictive or explanatory value with respect to changes in price levels could be constructed. We have carried out only a test of the usefulness of the structural variables for a period, combined with the structural equations for a previous period, in explaining price levels and changes in them. Since the relative form of PPP theory implies no change in price levels, any contribution these equations and/or changes in these variables can make in explaining price level changes is an improvement on the theory.

Our test asks whether the structure of one period and the observed values of the independent variables for the next period, predict the next period's price levels. Because we know that the deviations from the structural equation tend to persist from period to period, we include each period's deviations in the equation for the following period.

The predictions of price levels for all eight cross sections combined are shown in equation 6. It is based on structural equations with $r$, OPTT, the cross-product term rOPTI, and STI as independent variables. 
(6)

$$
\begin{aligned}
& \mathrm{PL}_{\mathrm{t}}=\underset{(1.63)}{4.22}+\underset{(25.10)}{.93(\hat{\mathrm{PL}}) t}+\frac{.73 \mathrm{RES}}{(8.10)^{-1}} \\
& \bar{R}^{2}=.801 \\
& \text { RMSE }=12.1 \\
& \text { No. Obs. }=173 \\
& \left(\hat{P L}_{t}=\text { Estimated price level for period } t\right. \text { based }
\end{aligned}
$$

Despite the changes over time in the structural relationships

recorded in Table 4, each period's price level was very well estimated from that period's structural variables in combination with the previous period's equation and the residuals from that equation. The implication of the coefficient on the residual is that these deviations from the structural relationships tended to persist from period to period but were reduced in size by about 20 per cent from one period to the next.

The corresponding equations for individual periods are given in Table 6 The predictions are quite good; all but one $\bar{R}^{2}$ are about .92 or over. The coefficients for the previous periods' residuals are always significant and generally below one, reflecting the persistence of the residuals but some tendency for them to decline over time.

These equations, although they account for so much of the variance in price levels, do not do much better in predicting price levels than the prediction of no change. Relative price levels are so strongly related to relative real income per capita, which changes very slowly, that it is hard to beat the no-change prediction by much. However, these equations provide estimates of changes in price levels, given changes in the independent variables. The interesting question is whether these predictions of changes in price level are superior to the prediction of no change. Equation 7 answers that question! 
Table 6

Estimation of Price Levels From Current Period r, OPTL, and STI, and Coefficients and Residuals from Previous Period Equations

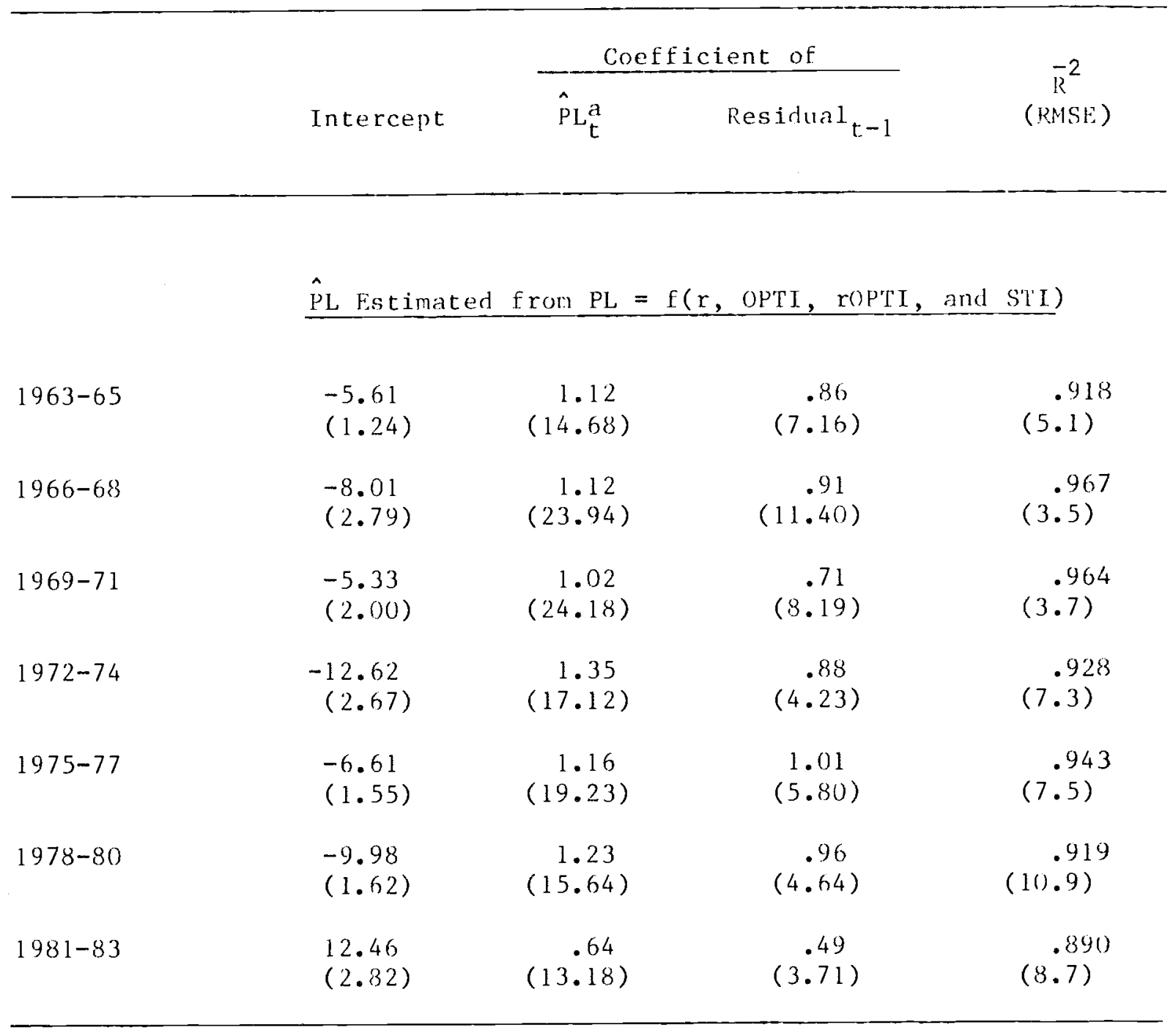

$\mathrm{a}_{\hat{\mathrm{p}}} \mathrm{L}_{t}$ is calculated using the coefficients from the equation

$P L_{t-1}=f\left(r_{t-1}\right.$, OPTI $t-1, r_{t-1}$ OPTI $I_{t-1}$ STI $\left.I_{t-1}\right)$ together with

the values of $r_{t}$, OPTI $t$, and STI $_{t}$. 
(7)

$$
\begin{aligned}
& \Delta P L_{t}=\frac{.050+.95}{(0.10)(18.60)}\left[\hat{P} L_{t}-P L_{t-1}\right] \\
& \bar{R}^{2}=.667 \\
& \text { RMSl: }=6.7 \\
& \text { No. Obs. }=173
\end{aligned}
$$

where $\Delta \mathrm{PL}_{t}=\mathrm{PL}_{t}-\hat{\mathrm{P}} \mathrm{L}_{t-1}$, and $\hat{\mathrm{PL}} \mathrm{t}_{\mathrm{t}}$ is the PL estimated in equation 6 .

The implication of these equations is that the structural equation for period t-l, the residuals fron that equation, and the changes in $r$, OPTI, and STI do, in combination, provide a predicted change in price level from period $t-1$ to period $t$ that is far better than the prediction of no change. These structural variables do help to explain changes in price level as we11 as differences at a given time.

The corresponding equations for individual periods are shown in Table 7. For five of the seven intervals the equations and changes in structural variables contribute significantly to estimating price level changes. The exceptions are two intervals in the 1970's when equations (not shown) fitted without the interaction term (rOPTI) provided sicrificantly better predictions.

The discussion up to this point has assumed that market forces operate on aggregate GDP price levels, price levels relative to those implied by structural equations, or changes in them, across countries. An alternative hypothesis is that these forces operate on traded goods prices but not, or to a much smaller extent, on nontradables prices. To test whether that is the case we will perform the same comparisons and tests on PLTR, the price level for tradables, as on the aggregate price level. 
Table 7

Estimation of Price Level Changes Fron Current-Period r, OPrT, and STI, and from Coefficients and Residuals from Previous-Period Equations

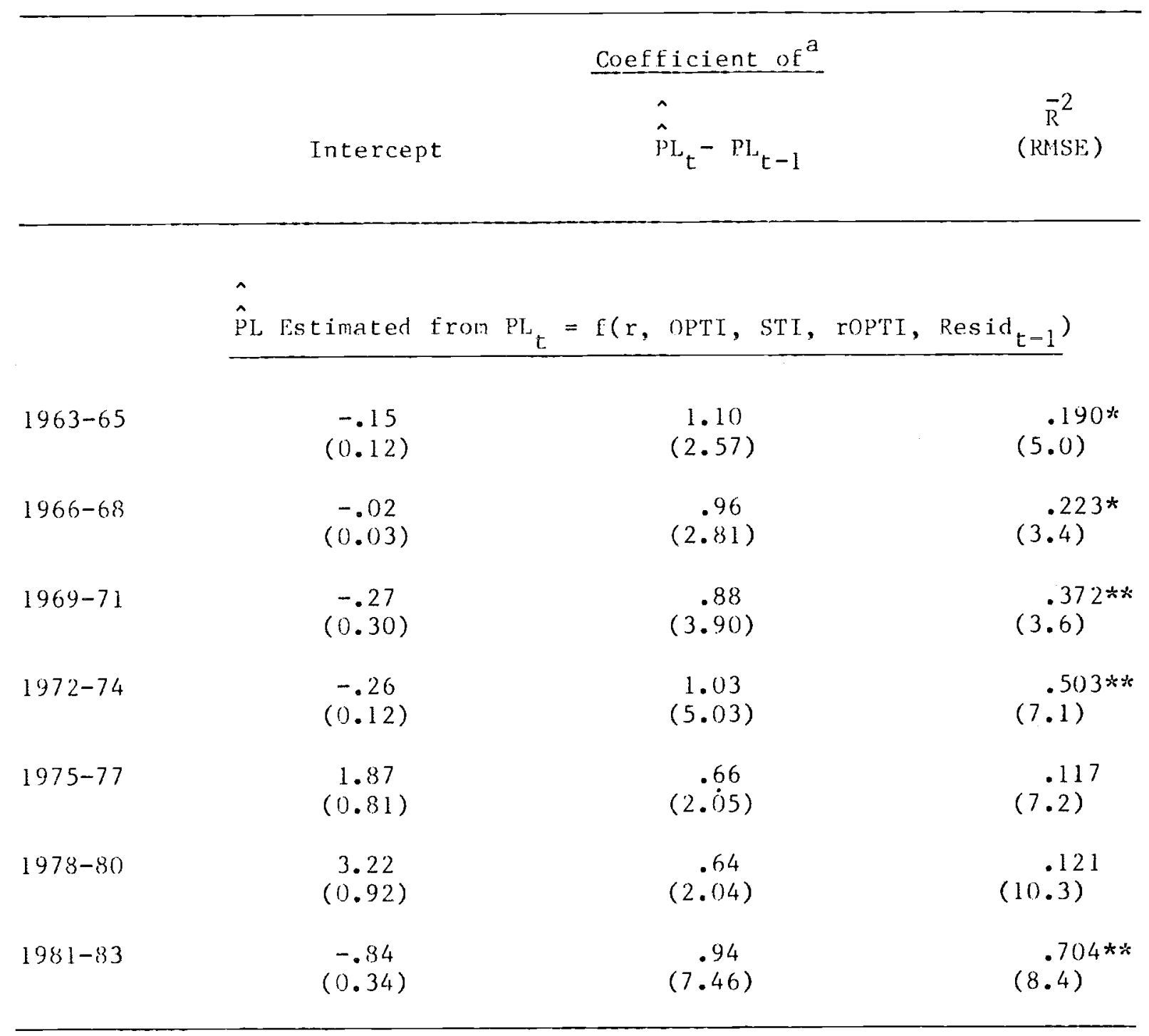

aFrom equation $\hat{\vec{p}}_{t}=f\left(\hat{P}_{L_{t}}, \operatorname{Resid} t_{t-1}\right)$

*Significant at 5 per cent level

* Significant at 1 per cent level 
$\underline{\text { Price Levels for Tradables and Nontradables }}$

The likelihood of large deviations from international equality of price levels is more readily acceptable for nontradables than for tradables, as is the possibility that price levels should be related to income or other variables. A number of theoretical analyses of price levels take account of this difference, as was pointed out in our earlier paper (Kravis and Lipsey, 1983). It was also pointed out there that, although the relationship was not quite as strong, the variables that explained aggregate price levels also went a long way in explaining price levels for tradables. That result does not necessarily contradict the theories that imply the equalization of prices of some type of "pure" tradables but it limits their empirical applicability. The measured prices of tradables inevitably incorporate some nontradable inputs, such as wholesale or retail services, and would differ among countries even if "pure" tradable prices were equalized.

There is a particular interest in the determinants of the two sets of prices separately, since we might expect that departures of tradables prices from equilibrium might be more quickly erased by changes in exchange rates than those of the total price level. They are also likely to be better indicators of any deliberate efforts by governments to influence trate flows and to be more influential in deternining trade flows.

For the benchmark year 1975, the equations for the price levels for GDP as a whole (PL) and for tradables (PLTR) and nontradables (PLNT), based on data for the 25 countries of Tables 1 and 2, are as follows:
(8) $\operatorname{PL}(75)$
$=25.94+.842 \mathrm{r}+6.74$ OPTI
$\overrightarrow{\mathrm{R}}^{2}=.864$
$(5.69) \quad(10.31) \quad(2.76)$
RMSE $=11.8$ 
(9)

$$
\begin{aligned}
\operatorname{PLTR}(75)= & 46.94+.673 \mathrm{r}+8.39 \text { OPTI } \\
& (7.77)(6.22) \\
\operatorname{PLNT}(75)= & 9.18+.946 \mathrm{r}+5.35 \text { OPTI } \\
& (2.45)(14.10) \\
& (2.67)
\end{aligned}
$$

As we might expect, the levels for nontradables prices are better explained than those for tradables prices, and the coefficient for $r$ is considerably higher. That seems reasonable in view of the explanations we have given for the relationship between income per capita and price levels. The coefficient for openness is larger in the equation for tradables, suggesting that the influence of competition with other countries plays more of a role for these products than for nontradables, in addition to effects of trade on factor prices.

In Table 8, similar equations for tradables and nontradables are fitted to data for our successive 3-year non-overlapping periods 21 . As in the benchmark year equations, the prices of nontradables, viewed across countries, rise more sharply with increasing per capita incomes ( $r$ ) than the prices of tradables. 22 The coefficients for openness, the ratio of goods actually traded to tradables, were similar in the two sets of equations, but the interaction between per capita income and openness was much stronger for nontradables.

\footnotetext{
$2 l_{\text {Only }} 19$ countries were included in the Table 8 regressions, because time series on GDP originating in different sectors in current and constant prices, necessary to derive implicit deflators for tradables and nontradables, were not available for the others. See notes to Table 8 . It should be added to those notes that the constant price series for the different economic sectors are in many instances subject to large margins of error and to country to country differences arising out of the use of different methods. We do not see any reason to believe that these incomparabilities bias the 19-country data in ways that invalidate our uses of them.
}

22 Tradables were defined as final expenditures on commodities other than construction in the benchmark year and as the output of agriculture, mining and manufacturing in the Table 8 equations. 
Table 8

Price levels for tradables (PLTR) and nontradables (PLNT) as functions of real per capita GDP ( $r$ ) and ratio of trade to tradable goods output (OPTI) Three year periods, 1960-62 to 1981-83

\begin{tabular}{|c|c|c|c|c|c|c|c|c|c|c|}
\hline & \multicolumn{5}{|c|}{ Tradables } & \multicolumn{4}{|c|}{ Nontradables } & \multirow[b]{3}{*}{$\begin{array}{c}\bar{R}^{2} \\
\text { (RMSE) } \\
\end{array}$} \\
\hline & \multirow[b]{2}{*}{ Intercept } & \multicolumn{3}{|c|}{ Coefficients of } & \multirow[b]{2}{*}{$\begin{array}{c}\overline{\mathrm{R}}^{2} \\
(\mathrm{RMSE})\end{array}$} & \multirow[b]{2}{*}{ Intercept } & \multicolumn{2}{|c|}{ Coefficients } & \multirow{2}{*}{$\frac{\text { of }}{\text { rOPTI }}$} & \\
\hline & & $r$ & OPTI & rOPTI & & & $\mathbf{r}$ & OPTI & & \\
\hline $1960-62$ & $\begin{array}{l}41.14 \\
(5.64)\end{array}$ & $\begin{array}{r}.572 \\
(3.69)\end{array}$ & $\begin{array}{l}14.16 \\
(1.82)\end{array}$ & $\begin{array}{l}-.157 \\
(.99)\end{array}$ & $\begin{array}{l}.590 \\
(11.4)\end{array}$ & $\begin{array}{l}13.18 \\
(2.43)\end{array}$ & $\begin{array}{c}.812 \\
(7.05)\end{array}$ & $\begin{array}{l}11.29 \\
(1.95)\end{array}$ & $\begin{array}{l}-.267 \\
(2.26)\end{array}$ & $\begin{array}{l}.809 \\
(8.5)\end{array}$ \\
\hline $1963-65$ & $\begin{array}{l}44.06 \\
(5.01)\end{array}$ & $\begin{array}{r}.551 \\
(3.08)\end{array}$ & $\begin{array}{l}11.33 \\
(1.18)\end{array}$ & $\begin{array}{r}-.047 \\
(.26)\end{array}$ & $\begin{array}{c}.590 \\
(12.9)\end{array}$ & $\begin{array}{c}8.42 \\
(1.57)\end{array}$ & $\begin{array}{c}8.91 \\
(8.17)\end{array}$ & $\begin{array}{l}13.47 \\
(2.29)\end{array}$ & $\begin{array}{l}-.251 \\
(2.27)\end{array}$ & $\begin{array}{l}.867 \\
(7.9)\end{array}$ \\
\hline $1966-68$ & $\begin{array}{l}39.41 \\
(4.48)\end{array}$ & $\begin{array}{r}.596 \\
(3.49)\end{array}$ & $\begin{array}{l}13.30 \\
(1.36)\end{array}$ & $\begin{array}{l}-.065 \\
(.37)\end{array}$ & $\begin{array}{c}.671 \\
(11.8)\end{array}$ & $\begin{array}{c}6.45 \\
(1.12)\end{array}$ & $\begin{array}{l}.912 \\
(8.16)\end{array}$ & $\begin{array}{l}12.43 \\
(1.94)\end{array}$ & $\begin{array}{l}-.195 \\
(1.71)\end{array}$ & $\begin{array}{r}.886 \\
7.8\end{array}$ \\
\hline $1969-71$ & $\begin{array}{l}39.46 \\
(5.52)\end{array}$ & $\begin{array}{r}.575 \\
(4.43)\end{array}$ & $\begin{array}{c}9.79 \\
(1.22)\end{array}$ & $\begin{array}{r}-.037 \\
(.29)\end{array}$ & $\begin{array}{l}.792 \\
(9.3)\end{array}$ & $\begin{array}{c}6.24 \\
(1.41)\end{array}$ & $\begin{array}{c}.867 \\
(10.75)\end{array}$ & $\begin{array}{c}8.00 \\
(1.60)\end{array}$ & $\begin{array}{l}-.133 \\
(1.67)\end{array}$ & $\begin{array}{l}.940 \\
(5.8)\end{array}$ \\
\hline $1972-74$ & $\begin{array}{l}44.08 \\
(5.36)\end{array}$ & $\begin{array}{r}.642 \\
(4.36)\end{array}$ & $\begin{array}{l}4.63 \\
(.54)\end{array}$ & $\begin{array}{l}.096 \\
(.73)\end{array}$ & $\begin{array}{l}.862 \\
(10.4)\end{array}$ & $\begin{array}{l}2.98 \\
(0.74)\end{array}$ & $\begin{array}{c}.974 \\
(13.49)\end{array}$ & $\begin{array}{c}6.83 \\
(1.62)\end{array}$ & $\begin{array}{c}-.038 \\
(.59)\end{array}$ & $\begin{array}{l}.972 \\
(5.1)\end{array}$ \\
\hline $1975-77$ & $\begin{array}{l}24.23 \\
(1.74)\end{array}$ & $\begin{array}{r}.851 \\
(3.65)\end{array}$ & $\begin{array}{l}28.97 \\
(2.14)\end{array}$ & $\begin{array}{l}-.199 \\
(1.02)\end{array}$ & $\begin{array}{l}.758 \\
(15.6)\end{array}$ & $\begin{array}{r}-1.23 \\
(.15)\end{array}$ & $\begin{array}{l}1.017 \\
(7.40)\end{array}$ & $\begin{array}{l}12.00 \\
(1.50)\end{array}$ & $\begin{array}{l}-.038 \\
(.33)\end{array}$ & $\begin{array}{l}.932 \\
(9.2)\end{array}$ \\
\hline $1978-80$ & $\begin{array}{l}40.09 \\
(2.96)\end{array}$ & $\begin{array}{r}.828 \\
(3.60)\end{array}$ & $\begin{array}{r}10.01 \\
(.94)\end{array}$ & $\begin{array}{l}.027 \\
(.17)\end{array}$ & $\begin{array}{l}.791 \\
(16.2)\end{array}$ & $\begin{array}{l}7.56 \\
(.84)\end{array}$ & $\begin{array}{r}1.026 \\
(6.69)\end{array}$ & $\begin{array}{l}1.35 \\
(.19)\end{array}$ & $\begin{array}{r}.142 \\
(1.35)\end{array}$ & $\begin{array}{c}.936 \\
(10.8)\end{array}$ \\
\hline $1981-83$ & $\begin{array}{l}36.19 \\
(3.23)\end{array}$ & $\begin{array}{r}.730 \\
(3.90)\end{array}$ & $\begin{array}{l}11.42 \\
(1.46)(\end{array}$ & $\begin{array}{l}-.15 \\
(1.30)\end{array}$ & $\begin{array}{c}.599 \\
(14.4)\end{array}$ & $\begin{array}{c}1.09 \\
(0.17)\end{array}$ & $\begin{array}{c}1.065 \\
(9.73)\end{array}$ & $\begin{array}{c}9.04 \\
(1.98)\end{array}$ & $\begin{array}{r}-.111 \\
(1.71)\end{array}$ & $\begin{array}{l}.927 \\
(8.4)\end{array}$ \\
\hline
\end{tabular}

a $\mathrm{PL}=\mathrm{F}(\mathbf{r}, \mathrm{OPTI}, \mathrm{rOPTI})$

Based on data for 19 countries, those listed in Table 1 with the exception of Luxembourg, Kenya, Malaysia, Malawi, Brazil, and Zambia. The 1975 PPPs for tradables and nontradables, derived from ICP exchange rates and price levels (Kravis, Heston and Sumners, 1982, pp. 10 and 196), were extrapolated to other years by the use of implicit deflators. The implicit deflator for tradables was derived by taking the ratio of GDP originating in agriculture, mining and manufacturing, at current prices to the GDP originating in these industries at constant prices (data from IBRD, 1984 Economic Data Shect 1). The implicit deflator for nontradables was formed in a similar way on the basis of GDP originating in other sectors. $r$ and OPTI were the same as in Table 2. 
In 1978-80, when the U.S. price level was very low, the coefficient for the interaction between real per capita income and openness is not only insignificant but even has the wrong sign.

III. Deviations From the Structural Equations and Their Significance The Pattern of Residuals

There are a number of ways to interpret the deviations of price levels from those predicted by our equations and to think about their consequences. If we regard the equations as representing estimates of equilibrium price levels, we might expect that deviations from them would be ephemera1. They might be quickly erased by movements of exchange rates, especially in the floating exchange rate period, or by price movements, especially in the fixed exchange-rate era. If the deviations are long-lasting, they might reflect the omission from our equations of significant structural variables, such as the inflow or outflow of capital. They might, on the other hand, reflect government policies that sustain disequilibrium price levels for long periods, for example by maintaining overvalued exchange rates and exchange controls or by maintaining undervalued rates to promote exports. 23

One way of analyzing the persistence of residuals is by measuring whether the countries that have high price levels (PL), relative to those predicted by the equations $(\hat{P} L)$, in one period tend to have high price levels in preceding or following periods. An answer to this question is given in

\footnotetext{
23 In this case, we might have to consider the possibility that our openness variable should be treated as partly endogenous. For example, an artificially sustained high exchange rate that produced a large positive deviation from the structural price level would reduce exports and perhaps force the country to cut imports as well. It might be appropriate to examine this possibility by substituting for openness itself a variable that represents the permanent determinants of openness, such as country size and population density.
} 
Table 9, which shows the correlations among residuals in different periods for the structural equations found in Table 4. Similar results are obtained when the other structural equations of Tables 2 and 3 are used. There is clearly a strong tendency for the deviations to be similar for a country in the different periods. Although the association atrophies with time, the correlation coefficients are all positive and are usually significant at the 5 per cent level $(r>.40)$ between a given period and each of three or four prior and three or four subsequent periods.

The 25 countries included in the analysis are grouped in Table 10 according to their long-run tendency to have low, intermediate or high price levels after the price levels have been purged of structural influences as measured by equation $4 \mathrm{~A}$, that is, after levels of real income per capita, openness, and the share of nontradables in output have been taken into account. For the most part, countries with actual PLs falling far short of the PLs estimated by the equation tended to have such shortfalls (negative residuals) consistently across the seven periods. ${ }^{24}$ Similarly, countries with

\footnotetext{
${ }^{24}$ The identification of the countries with low purged (or residual) price levels (i.e., PL-PL) or high ones is fairly robust to small changes in the specification of the structural equation, such as the use of OP or OPT instead of OPTI or the substitution of logs for arithmetic values. There is, however, the possibility that errors in the 1975 benchmark measures of PL are simply being extrapolated to other years. Some assurance that is not the case is given by a comparison of the 1980 PLs for 10 industrial countries extrapolated from our 1975 benchmarks with the 1980 PLs produced by a new OECD benchmark study (Hill 1985), most of the data representing comparisons carried out by the Statistical office of the European Community (1982). The coefficient of rank correlation was 0.78 . The three countries with the lowest PLs were identical and so were the three with the highest PLs, though within neither set of three were the rankings identical and a fourth country was in a tie for the eighth rank (from low to high) in our estimates. The possibility remains, of course, that the statistical system of the country, which provides the basic data for the international comparisons, produces prices or expenditures that are biased relative to those produced by other countries. The reasonableness of the conformances of the benchmark series does not provide proof against this untoward outcome.
} 
Table 9

Correlation Matrix for Residuals fron Equations Estimating Price Levelsa

25 Countries $^{\mathrm{b}}, 1960-83$

\begin{tabular}{lcccccccc}
\hline \multicolumn{1}{c}{$1960-62$} & $1963-65$ & $1966-68$ & $1969-71$ & $1972-74$ & $1975-77$ & $1978-80$ & $1981-83$ \\
\hline $1960-62$ & 1.00 & .84 & .83 & .58 & .30 & .35 & .09 & .25 \\
$1963-65$ & .84 & 1.00 & .93 & .72 & .54 & .48 & .28 & .33 \\
$1966-68$ & .83 & .93 & 1.00 & .87 & .70 & .60 & .45 & .46 \\
$1969-71$ & .58 & .72 & .87 & 1.00 & .71 & .52 & .46 & .50 \\
$1972-74$ & .30 & .54 & .70 & .71 & 1.00 & .83 & .79 & .55 \\
$1975-77$ & .35 & .48 & .60 & .52 & .83 & 1.00 & .75 & .46 \\
$1978-80$ & .09 & .28 & .45 & .46 & .79 & .75 & 1.00 & .72 \\
$1981-83$ & .25 & .33 & .46 & .50 & .56 & .46 & .72 & 1.00
\end{tabular}

a Residuals for each period equal actual PL minus PL estimated from

equation ( $\hat{\mathrm{PL}})$. The equation used here is $\mathrm{PL}=\mathrm{f}(\mathrm{r}, \mathrm{OPTI}, \mathrm{rOPTI}, \mathrm{STI})$.

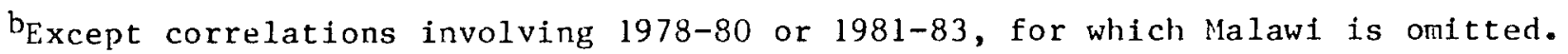


Table 10

Countries Arrayed by Residual Price Level After Allowing for Structural PL Determinants 1960-83 (Low to high)

\begin{tabular}{|c|c|c|c|c|c|c|c|c|}
\hline \multicolumn{9}{|c|}{ Countries with } \\
\hline \multicolumn{3}{|c|}{ Low price levels } & \multicolumn{3}{|c|}{ Intermediate price levels } & \multicolumn{3}{|c|}{ lligh price levels } \\
\hline Country & Rank & $\begin{array}{l}\text { Periods } \\
\text { with }+ \\
\text { residual }\end{array}$ & Country & Rank & $\begin{array}{l}\text { Periods } \\
\text { with }+ \\
\text { residual }\end{array}$ & Country & Rank & $\begin{array}{l}\text { Periods } \\
\text { with }+ \\
\text { residual }\end{array}$ \\
\hline Uruguay & 1 & 0 & Mexico & 9 & 2 & Kenya & 17 & 7 \\
\hline Sri Lanka $a^{\mathrm{n}}$ & 2 & 3 & Austria ${ }^{p}$ & 10 & 3 & U.K. & 18 & 6 \\
\hline Korea & 3 & 0 & Pakistan & 11 & 2 & Philippines & s 19 & 6 \\
\hline Malaysia ${ }^{p}$ & 4 & 0 & India & 12 & 4 & Germany & 20 & 4 \\
\hline U.s. ${ }^{n}$ & 5 & 4 & Belgium & 13 & 7 & Deninark & 21 & 6 \\
\hline Colombia & 6 & 1 & Japan & 14 & 4 & Italy & 22 & 8 \\
\hline Thailand & 7 & 0 & Jamaica & 15 & 5 & Zambia ${ }^{p}$ & 23 & 8 \\
\hline Luxembourg & 8 & 3 & France $^{n}$ & 16 & 6 & Brazil & 24 & 8 \\
\hline
\end{tabular}

Rank: Based on residuals from equations of the form $4 A C$ : PL $=f(r$, OPTI, rOPTI, STI ). The equation was fitted to each of eight non-overlapping three-year periods beginning with 1960-62 and ending with 1981-83. The residuals were averaged and the countries ranked, beginning with the one with the largest negative average residual. Malawi was omitted from the ranking because its price level was not available for all periods.

PThere was a positive trend in the residuals. The criterion was a $5 \%$ significance level

for the coefficient of time ( $T$ ) in the equation:

Residual $=a+b T$

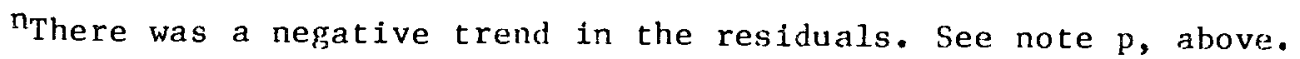


actual PLs far exceeding estimated PLs tended to have positive residuals that also appeared rather consistently. Trends in the residuals characterized several countries, as noted in the table. One of the pronounced ones was for the U.S.; the U.S. residual moved almost monotonically from +9.2 in $1960-62$ to -31.4 in 1978-80 but then declined sharply in absolute terms in the last period. The behavior of price residuals for developed countries was somewhat different from that for developing countries. In particular, all the 7 countries with consistent low residual price levels (negative residuals in 6 , 7 , or 8 periods, were developing countries.

Since the structural equations come closer than identity of price levels to a representation of equilibrium price levels, the residuals from identical price levels should be more persistent. Table 11 shows the persistence of deviations from purchasing power parity, as measured by the correlations between PLs in different periods. 25 As we hypothesized, these deviations are more persistent than those from the structural equations of Table 9. The differences between the two sets of deviations are summarized below:

25 It is conceivable that the correlations are high because of non-persistent variations in $\mathrm{PL}$, but the frequent persistence of high or low deviations (Table 10) makes this unlikely. 
Table 11

Correlation Matrix for Price Levels in Eight Three-Year Periods ${ }^{a}$

\begin{tabular}{ccccccccc}
\hline & $1960-62$ & $1963-65$ & $1966-68$ & $1969-71$ & $1972-74$ & $1975-77$ & $1978-80$ & $1981-1983$ \\
\hline $1960-62$ & 1.00 & .95 & .94 & .87 & .79 & .75 & .69 & .76 \\
$1963-65$ & .95 & 1.00 & .98 & .93 & .88 & .83 & .78 & .84 \\
$1966-68$ & .94 & .98 & 1.00 & .97 & .93 & .88 & .84 & .87 \\
$1969-71$ & .87 & .93 & .97 & 1.00 & .95 & .91 & .88 & .92 \\
$1972-74$ & .79 & .88 & .93 & .95 & 1.00 & .98 & .96 & .95 \\
$1975-77$ & .75 & .83 & .88 & .91 & .98 & 1.00 & .97 & .94 \\
$1978-80$ & .69 & .79 & .84 & .88 & .96 & .97 & 1.00 & .95 \\
$1981-83$ & .76 & .84 & .87 & .92 & .95 & .94 & .95 & 1.00 \\
\hline
\end{tabular}

a(PL-100) for each period (that is, deviations from the identity of price levels implied by the absolute form of the purchasing power parity theory). . 


\begin{tabular}{|c|c|c|c|c|}
\hline Length of span & No. of & Average of & relati & on Coef \\
\hline (periods) & Obs. & $\underline{\text { Price Levels }}^{\mathrm{b}}$ & Price & Leve1 \\
\hline 1 & 7 & .96 & & .81 \\
\hline 2 & 6 & .94 & & .67 \\
\hline 3 & 5 & .89 & & .55 \\
\hline 4 & 4 & .84 & & .43 \\
\hline 5 & 3 & .80 & & .36 \\
\hline 6 & 2 & .76 & & .21 \\
\hline 7 & 1 & .76 & & .25 \\
\hline Al1 spans & 28 & .89 & & .57 \\
\hline
\end{tabular}

a Each correlation is between two sets of average PLs or two sets of PL residuals for 25 countries, each set relating to a different 3-year period.

$\mathrm{b}_{\text {Table }} 11$

$\mathrm{c}_{\text {Table }} 9$

The correlations between price levels (that is, deviations from purchasing power parity) in one period and those in succeeding periods are higher than those for the residuals from the structural equations for every length of span, but the differences are much greater for the longer spans. In other words, a country with a high price level in one year is likely to have a high price level 20 years later. On the other hand, a country with a high price level relative to its structural characteristics, while it will be likely to still have a high price level three years later, is not particularly likely to have such a price level 15 or 20 years later. Our interpretation of this difference is that the deviations from the levels predicted by the structural equations of Table 4 represent something more like departures from long-run equilibrium 
price levels than the departures from purchasing power parity (equality of price levels). The latter represent not only deviations from equilibrium but also reflect long-run structural characteristics of the economies.

\section{$\underline{\text { Residuals for Tradables and Nontradables }}$}

If equilibrium is more likely to be attained for tradables prices than for PL as a whole, and if exchange rates are not too greatly affected by intervention, deviations from the tradables equations might be expected to be less persistent than those for PL. That proposition is tested in Table 12, a companion to Table 9, but based on deviations of tradables prices from their structural equations.

Within the fixed-rate era there was little difference in persistence between tradables residuals and those for the aggregate price level, as can be seen below. Within the floating-rate period, the residuals for tradables

Average Correlation Coefficients Between Residuals for PLs for Different Periods Price Levels for Tradables and for Aggregate GDP

$\frac{\text { PL for Tradables }}{\text { No. of Pairs Av. Coeff. No. of. Pairs Av. Coeff. }}$

$\begin{array}{lrrrrr}\text { Within the Bretton Woods regime } & 6 & .81 & 6 & .80 \\ \text { Within the floating-rate regime } & 6 & .63 & 6 & .68 \\ \text { Between the two regimes } & 16 & .38 & 16 & .44\end{array}$

\footnotetext{
a Table 12

bThese figures differ from those derived earlier from Table 9 because they refer to only 19 countries, to match the data for tradables prices.
} 
Table 12

Correlation Matrix for Residuals from Structural Equations Estimating

Tradables Price Levels (PLTR) for Eight Three-Year Periods ${ }^{\text {a }}$

19 Countries $b, 1960-83$

$\begin{array}{llllllll}1960-62 & 1963-65 & 1966-68 & 1969-71 & 1972-74 & 1975-77 & 1978-80 & 1981-83\end{array}$

\begin{tabular}{rrrrrrrrr}
$1969-62$ & 1.00 & .82 & .86 & .65 & .21 & .36 & .17 & .31 \\
$1963-65$ & .82 & 1.00 & .90 & .72 & .41 & .50 & .26 & .33 \\
$1966-68$ & .86 & .90 & 1.00 & .88 & .45 & .60 & .28 & .26 \\
$1969-71$ & .66 & .72 & .88 & 1.00 & .54 & .68 & .41 & .36 \\
$1972-74$ & .21 & .41 & .45 & .54 & 1.00 & .82 & .71 & .31 \\
$1975-77$ & .36 & .50 & .60 & .68 & .82 & 1.00 & .72 & .47 \\
$1978-80$ & .17 & .26 & .28 & .41 & .71 & .72 & 1.00 & .73 \\
$1981-83$ & .31 & .33 & .26 & .36 & .31 & .47 & .73 & 1.00 \\
\hline
\end{tabular}

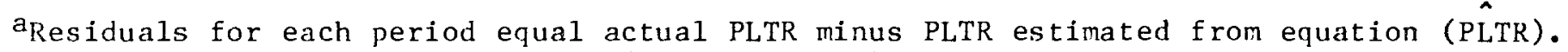
The equation used here is $\mathrm{PLTR}=\mathrm{f}(\mathrm{r}, \mathrm{OPTI}$, rOPTI $)$.

${ }^{b}$ See Table 13 for list of countries. 
were a little less persistent than those for nontradables and the same was true for intervals spanning the two periods.

To the extent that persistently high or low price levels relative to those predicted by our equations represent policies of raising or depressing exchange rates rather than unaccounted-for characteristics of the economies, we might expect that they will operate equally on both tradable and nontradable price levels. Also from a purely statistical standpoint, the shared importance of tradables and nontradables in constituting GDP makes it unsurprising that countries that tend to have high predicted price levels for aggregate GDP generally tend to have high predicted price levels also for the tradable and nontradable components of GDP. 26 However, the connections were not so close that there was not room for a variety of patterns; the coefficient of correlation linking the PLTR and PLNT residuals was only .52. Thus, some countries had higher price levels for tradables relative to nontradables than would be expected on the basis of the equations, and others exhibited the opposite relationship. The prices of tradables were substantially higher.in these terms in Mexico, India, France, and Uruguay and substantially lower in Belgium, Korea, Thailand, and Japan (Table 13). 27 Price Level Deviations and the Current Account Balance If the deviations from our equations represent departures from some

\footnotetext{
$26_{\text {For }}$ the 19 countries in Table 13, the coefficient of correlation between the residuals from the PL equations and those from the PLTR equations was .87; that between the residuals of the PL equations and the PLNT equations was . 72 . The residuals in these correlations were those obtained by averaging 7 sets of residuals, one relating to each of the seven periods.

27 It would be interesting to investigate both the causes and consequences of these differing price relationships, but that must remain a matter for future research. (See, however, Kravis, Heston and Summers, 1983, and Kravis and Lipsey, 1983 for the role of service prices which comprise the bulk of nontradables).
} 
Table 13

Ranks of Countries According to Size of Residuals from Equations

Explaining PL, PLTR, and PLNT ${ }^{\mathrm{a}}$

\section{Low Price Levels}

\begin{tabular}{|c|c|c|c|}
\hline$P L-\hat{P} L$ & & $\begin{array}{l}\text { PLTK- } \\
\text { P̂TK }\end{array}$ & $\begin{array}{l}\text { PLNT } \\
\text { PÂNT }\end{array}$ \\
\hline 1 & Uruguay b & 1 & 1 \\
\hline 2 & Sri Lanka ${ }^{b}$ & 4 & 2 \\
\hline 3 & Korea $^{b}$ & 3 & 6 \\
\hline 4 & U.s. ${ }^{b}$ & 5 & 9 \\
\hline 5 & Belgium & 6 & 11 \\
\hline 6 & Thailand ${ }^{b}$ & 2 & 14 \\
\hline
\end{tabular}

Intermediate Price Levels

$$
P L-\hat{P L}
$$

PLTR- PLNT-

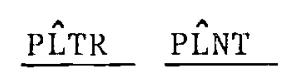

7 Colombia

8 Austriab

9 Germany

10 Mexico ${ }^{b}$

11 Indiab

12 France $^{b}$

13 Denmark
High Price Levels

\begin{tabular}{|c|c|c|c|}
\hline \multicolumn{2}{|c|}{$P L-P L$} & \multirow{2}{*}{$\begin{array}{l}\text { PLTR- } \\
\text { PिLTR } \\
13\end{array}$} & \multirow{2}{*}{ 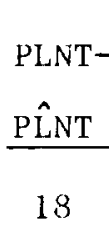 } \\
\hline 14 & Pakistan & & \\
\hline 15 & Japan & 8 & 19 \\
\hline 16 & U.K. ${ }^{b}$ & 15 & 13 \\
\hline 17 & Phil. b & 14 & 12 \\
\hline 18 & Jama i ca & 19 & 17 \\
\hline 19 & Italyb & 18 & 16 \\
\hline
\end{tabular}

Karet $\left({ }^{\wedge}\right)$ represents estimate from equation. PL - Price level for GDP;

PLTR = Price level for tradables; PLNT = Price level for nontradables.

${ }^{a}$ Countries are ranked fron large negative values of the residuals to high positive ones. The residuals are averages of those from the 7 equations, one for each period. For equations with PL as the dependent variable, $r$, OPTI, rOPTI, and STI were the independent variables. For the equations explaining, PLTR and PLNT, $r$, OPTI, and rOPTI were the independent variables.

${ }^{b}$ Country is classified in same price level group (i.e., low, intermediate or high) in Table 10. 
sort of long-term relationship, we might expect then to have effects on subsequent flows of exports and imports of goods and services. A high price level

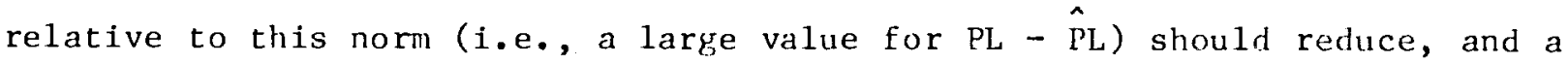
low price level should increase, exports relative to imports. This possibility is tested in Table 14, in which we relate the price level deviations in the first and fourth periods to changes in the export/import ratio between those periods and the seventh and eighth periods, the longest spans for which we have data.

The results give consistent, but weak support for the idea that some such long-term relationships exist. A high price level in 1969-71 relative to that predicted by a country's real income per capita, degree of openness, and share of tradables in output was associated with a decline in exports relative to imports over the period to 1978-80, but the relationship was much weaker with the period ending in 1981-83. However, equations with fewer variables (not shown) produced significant correlations over three of the five spans. Over shorter periods, the coefficients were quite erratic and only one was significant at the 1 per cent level: a high price level in 1969-71 was associated with declines in the export/import ratio in the next period.

Given all that we know about the factors determining trade flows, it is obvious that we have not specified a trade equation here. The most we night say is that there is some indication that it may be worth including some such measures of general price levels in more completely specified trade equations, in addition to the usual measures of price change for specific products or groups of products. 


\section{Summary and Agenda for Future Research}

This paper starts from the fact that neither the absolute nor the relative version of purchasing power parity theory provides an adequate explanation for differences in national price levels. The former assumes that all price levels are equal and the latter that they all change by identical proportions. We have tried to find explanations for the price level differences that exist and for changes in relative levels that would be superior to those assumptions. Fron these explanations, we attempt to derive some norms for national price levels.

The structural determinants of national price levels discovered in previous studies of data for 1975 and earlier years were still evident in the latest and much broader survey covering 55 countries in 1980. We fitted similar cross sections to a number of sub-periods over 23 years, relating price levels to real income per capita, the openness of the economy, and, the share of tradables in total output.

These equations suggested that since 1960 or even 1950 , there has been a movement towards a more "orderly" alignment of price levels. That is, national price levels came to be explained to an increasing degree by our structural variables. Most of that increase in orderliness took place before the $1970^{\prime} \mathrm{s}$. The degree to which these structural variables explained price levels remained roughly constant after that and even declined a bit in the last period, $1981-83$.

The higher the real income per capita of a country, the higher was its price level. In general, a greater degree of openness of an economy is also associated with a higher price level, but there are indications that that 
relationship varies by income level. In poor countries, more openness is associated with higher price levels; in rich countries with lower price levels.

The coefficients of the structural equations changed substantially over time, the most important change being a gradual increase in the coefficient for real income per capita, at least through the end of the 1970's. We have not so far been able to explain the changes in coefficients.

Various tests suggest that equations including variables such as these do provide better explanations of both price levels and changes in price levels than do assumptions of equality of levels or of changes in them. Furthermore, deviations of price levels from the norms provided by these equations are associated with movements back towards the norms over intervals of several years and even over periods of one or two decades.

If the price level norms estimated from our equations are a better approximation to long-term equilibrium levels than those implied by purchasing power parity theory, the deviations of actual pLs from their estimated values should tend to be less persistent over time. This does prove to be the case. The correlation between deviations from PPP in one period and in other periods was still above .75 after 20 years or more, while that for deviations from the structural equations were lower than that after five years, and only about .20 after two decades. The persistence of deviations from the equations seemed to be less under floating exchange rates than under fixed exchange rates and least across the change in regimes.

To the extent that the deviations from our structural relationships represent departures from sustainable long-term relationships, they might be expected to influence trade flows. We find that, in fact, a high price level, 
relative to the norm, was consistently associated with a decline in exports relative to imports over the next decade or two, although many of the coefficients were not significant. The relationship was much weaker and nore erratic, however, over three-year intervals.

We do not imagine that the last word has been said on the specification of the structural equation. The next steps include a search for explanations of the residuals to the structural equations. As suggested, short-run influences may be expected to account for some of the deviations of actual pls from those predicted by the structural equations. Their inclusion might improve the estimates of the structural equations as well as help to explain the deviations from them. The deviations that persist over many years, found in this paper for a number of countries, may prove to be explicable in terms of long-run factors as yet unidentified. Finally, the residuals appear to have economic consequences, such as those on trade flows that deserve to be investigated further. 
List of References

Berglas, Eitan, and Assaf Razin (1973), "Real Exchange Rate and Devaluation," Journal of International Economics, 3 (May), pp. 179-192.

Bhagwati, Jagdish, N. (1984), "Why are Services Cheaper in Poor Countries?," Economic Journal, Vo1. 94, No. 374, June, pp. 279-286.

Bushe, Dennis, Irving B. Kravis, and Robert E. Lipsey (1986), "Prices, Activity, and Machinery Exports: An Analysis Based on New Price Data," forthcoming in the Review of Economics and Statistics.

Clague, Christopher (1986), "Determinants of the National Price Leve1: Some Empirical Results," Review of Economics and Statistics, forthcoming.

Gilbert, Milton, and Irving B. Kravis (1954), An International Comparison of National Products and Purchasing Power of Currencies: A Study of the U.S., the U.K., France, Germany, and Italy, Paris, OEEC. and Associates (1958), Comparative National Products and Price Levels, Paris, OEEC.

Hi11, Peter (1984), "Real Gross Product in OECD Countries and Associated Purchasing Power Parities," OECD Economics and Statistics Department Working Papers, No. 17 (December).

Kravis, Irving B. (1984), "Comparative Studies of National Income and Prices," Journal of Economic Literature, XXII.

Kravis, Irving B., Alan Heston, and Robert Summers (1978), "Real GDP per Capita for More Than One Hundred Countries," Economic Journa1, 88 (June), pp. $215-242$.

, and (1980), "Internationa 1 Comparison of $\overline{R e a 1}$ Product and its Composition: $1950-77$, "Review of Income and Wealth, Series 26, No. 1, March.

, and (1982), World Product and Income: International Comparisons of Real GDP, Baltimore, Johns Hopkins Press.

L, and (1983), "The Share of Services in Economic Growth," in Global Econometrics: Essays in Honor of Lawrence R. Klein, F.G. Adams and Bert Hickman, eds., MIT Press, Cambridge. 
Kravis, Irving B., and Robert E. Lipsey (1978), "Price Behavior in the Light of Balance of Payments Theories," Journal of International Economics, Vo1. 8, No. 2 (May), pp. 193-246.

, and (1983), Toward an Explanation of National Price Levels, Princeton Studies in International Finance, No. 52.

, and

(1984), "The Diffusion of Economic Growth in the World Economy, 1950-1980," in International Comparisons of Productivity and Causes of the Slowdown, ed. by John W. Kendrick, Ballinger Publishing Co., Cambridge, MA.

Krueger, Anne 0. (1983), Exchange-Rate Determination, Cambridge Surveys of Economic Literature, Cambridge University Press, Cambridge.

Lipsey, Robert E. (1934), "Recent Trends in U.S. Trade and Investment," in Problems of Advanced Economies, Proceedings of the Third Conference on Advanced Societies, ed. by Nagasada Miyawaki, Springer-Verlag, Berlin and Heidelberg.

Statistical office of the European Communities (Furostat) (1983), Comparison in Real Values of the Aggregates of ESA, 1980, Luxembourg.

(1985), Comparison of Price Levels and Economic Aggregates: The Resu1ts for Fifteen African Countries, 1980, Luxembourg.

Summers, Robert, Irving B. Kravis, and Alan Heston (1980), "Internationa1 Comparisons of Real Product and its Composition: 1950-77," The Review of Income and Wealth, Series 26, No. 1 (March).

U.S. Department of Commerce (1983), Summary Input-Output Tables of the U.S. Economy: 1976, 1978, and 1979, by Paula C. Young and Mark A. Planting, Bureau of Economic Analysis Staff Paper 39, January.

Ward, Michael (1985), Purchasing Power Parities and Real Expenditures in the OECD, Paris, OECD.

Zellner, Arnold (1962), "An Efficient Method of Estimating Seeming1y Unrelated Regressions and Tests for Aggregation Bias," Journal of the American Statistical Association, Vo1. 57, 298 (June).

(1963), "Estimates for Seemlingly Unrelated Regression Equations: Some Exact Finite Sample Results,", Journal of the American Statistical Association, Vo1. 58, 304 (December). 
Appendix Table 1

Price Leve1 (PL) as a Function of $r$, OPTI, rOPTI, and STI Three-Year Periods, 1960-83, 24 Countries

Results based on Seemingly Unrelated Regression procedure

\begin{tabular}{|c|c|c|c|c|c|}
\hline & Intercept & $r$ & OPTI & rOPTI & $\operatorname{STI}$ \\
\hline $1960-62$ & $\begin{array}{l}56.49 \\
(5.11)\end{array}$ & $\begin{array}{r}.541 \\
(5.26)\end{array}$ & $\begin{array}{c}4.67 \\
(1.16)\end{array}$ & $\begin{array}{r}-.125 \\
(1.74)\end{array}$ & $\begin{array}{c}-.40 \\
(2.17)\end{array}$ \\
\hline $1963-65$ & $\begin{array}{l}51.90 \\
(4.43)\end{array}$ & $\begin{array}{r}.607 \\
(5.71)\end{array}$ & $\begin{array}{l}3.96 \\
(.90)\end{array}$ & $\begin{array}{c}-.110 \\
(1.54)\end{array}$ & $\begin{array}{c}-.32 \\
(1.71)\end{array}$ \\
\hline $1966-68$ & $\begin{array}{l}51.24 \\
(4.93)\end{array}$ & $\begin{array}{r}.657 \\
(6.34)\end{array}$ & $\begin{array}{c}5.44 \\
(1.20)\end{array}$ & $\begin{array}{r}-.124 \\
(1.64)\end{array}$ & $\begin{array}{c}-.39 \\
(2.18)\end{array}$ \\
\hline $1969-71$ & $\begin{array}{l}40.34 \\
(4.16)\end{array}$ & $\begin{array}{r}.663 \\
(7.46)\end{array}$ & $\begin{array}{l}3.95 \\
(.99)\end{array}$ & $\begin{array}{c}-.092 \\
(1.52)\end{array}$ & $\begin{array}{c}-.23 \\
(1.35)\end{array}$ \\
\hline $1972-74$ & $\begin{array}{l}29.88 \\
(2.36)\end{array}$ & $\begin{array}{r}.877 \\
(7.76)\end{array}$ & $\begin{array}{c}8.70 \\
(1.80)\end{array}$ & $\begin{array}{r}-.114 \\
(1.65)\end{array}$ & $\begin{array}{c}-.12 \\
(0.58)\end{array}$ \\
\hline $1975-77$ & $\begin{array}{l}52.17 \\
(2.89)\end{array}$ & $\begin{array}{r}.831 \\
(5.66)\end{array}$ & $\begin{array}{l}14.37 \\
(2.35)\end{array}$ & $\begin{array}{r}-.135 \\
(1.74)\end{array}$ & $\begin{array}{c}-.67 \\
(2.17)\end{array}$ \\
\hline $1978-80$ & $\begin{array}{l}49.73 \\
(2.27)\end{array}$ & $\begin{array}{r}.951 \\
(5.35)\end{array}$ & $\begin{array}{c}7.58 \\
(1.18)\end{array}$ & $\begin{array}{c}-.038 \\
(.45)\end{array}$ & $\begin{array}{c}-.49 \\
(1.22)\end{array}$ \\
\hline $1981-83$ & $\begin{array}{l}54.80 \\
(3.03)\end{array}$ & $\begin{array}{r}.754 \\
(5.73)\end{array}$ & $\begin{array}{c}6.56 \\
(1.49)\end{array}$ & $\begin{array}{r}-.097 \\
(1.78)\end{array}$ & $\begin{array}{c}-.66 \\
(1.95)\end{array}$ \\
\hline
\end{tabular}


Appendix Table 2

Price level for Tradables (PLTR) as a Function of $r$, OPTI, and rOPTL Three-Year Periods, 1960-83, 19 Countries

Results based on Seeringly Unrelated Regression Procedure

\begin{tabular}{|c|c|c|c|c|}
\hline & Intercept & $r$ & optL & rOPTI \\
\hline $1960-62$ & $\begin{array}{l}46.04 \\
(7.29)\end{array}$ & $\begin{array}{r}.553 \\
(3.97)\end{array}$ & $\begin{array}{c}7.98 \\
(1.25)\end{array}$ & $\begin{array}{l}-.122 \\
(.87)\end{array}$ \\
\hline $1963-65$ & $\begin{array}{l}52.89 \\
(7.09)\end{array}$ & $\begin{array}{r}.505 \\
(3.18)\end{array}$ & $\begin{array}{l}.22 \\
(.03)\end{array}$ & $\begin{array}{l}.028 \\
(.18)\end{array}$ \\
\hline $1966-63$ & $\begin{array}{l}46.71 \\
(6.43)\end{array}$ & $\begin{array}{r}.569 \\
(3.82)\end{array}$ & $\begin{array}{l}4.64 \\
(.61)\end{array}$ & $\begin{array}{r}-.016 \\
(.11)\end{array}$ \\
\hline $1969-71$ & $\begin{array}{l}45.05 \\
(7.38)\end{array}$ & $\begin{array}{r}.562 \\
(4.85)\end{array}$ & $\begin{array}{l}3.35 \\
(.51)\end{array}$ & $\begin{array}{l}-.007 \\
(.06)\end{array}$ \\
\hline $1972-74$ & $\begin{array}{l}52.04 \\
(7.07)\end{array}$ & $\begin{array}{r}.600 \\
(4.37)\end{array}$ & $\begin{array}{r}-4.95 \\
(.67)\end{array}$ & $\begin{array}{r}.178 \\
(1.51)\end{array}$ \\
\hline $1975-77$ & $\begin{array}{l}35.73 \\
(2.96)\end{array}$ & $\begin{array}{r}.793 \\
(3.76)\end{array}$ & $\begin{array}{l}15.08 \\
(1.42)\end{array}$ & $\begin{array}{l}-.089 \\
(.53)\end{array}$ \\
\hline $1978-80$ & $\begin{array}{l}49.74 \\
(3.99)\end{array}$ & $\begin{array}{r}.762 \\
(3.49)\end{array}$ & $\begin{array}{l}.83 \\
(.09)\end{array}$ & $\begin{array}{l}.117 \\
(.81)\end{array}$ \\
\hline $1981-83$ & $\begin{array}{l}41.83 \\
(4.03)\end{array}$ & $\begin{array}{r}.693 \\
(3.95)\end{array}$ & $\begin{array}{l}6.46 \\
(.91)\end{array}$ & $\begin{array}{r}-.098 \\
(.96)\end{array}$ \\
\hline
\end{tabular}

